\title{
Progress or Regress? A Systematic Review on Two Decades of Monitoring and Addressing Land Subsidence Hazards in Semarang City
}

\author{
Rizkiana Sidqiyatul Hamdani ${ }^{1, *}$, Sudharto Prawata Hadi ${ }^{1}$ and Iwan Rudiarto ${ }^{1,2}$ D \\ 1 Graduate Study Program of Environmental Sciences, School of Postgraduate Studies, Diponegoro University, \\ Semarang 50241, Indonesia; sudhartophadi@yahoo.co.id (S.P.H.); iwan.rudiarto@pwk.undip.ac.id (I.R.) \\ 2 Department of Urban and Regional Planning, Diponegoro University, Semarang 50275, Indonesia \\ * Correspondence: rizkiana@students.undip.ac.id
}

Citation: Hamdani, R.S.; Hadi, S.P.; Rudiarto, I. Progress or Regress? A Systematic Review on Two Decades of Monitoring and Addressing Land Subsidence Hazards in Semarang City. Sustainability 2021, 13, 13755. https://doi.org/10.3390/su132413755

Academic Editor: Luca Salvati

Received: 22 October 2021

Accepted: 26 November 2021

Published: 13 December 2021

Publisher's Note: MDPI stays neutral with regard to jurisdictional claims in published maps and institutional affiliations.

Copyright: (c) 2021 by the authors. Licensee MDPI, Basel, Switzerland. This article is an open access article distributed under the terms and conditions of the Creative Commons Attribution (CC BY) license (https:// creativecommons.org/licenses/by/ $4.0 /)$.

\begin{abstract}
Land subsidence is a major cause of environmental degradation. It increases the exposure of global sea level rise-related disasters in coastal cities lying on young sediment. Ample monitoring, adaptation, and mitigation measures have been taken to tackle the impact of such coastal hazards for decades in Semarang City. However, to date, land subsidence still has a negative impact on people's quality of life. This brings us to the question of whether the measures are progressing towards better management or going to the opposite side. This paper is aimed to answer that question through an extensive literature review using PRISMA Guidelines to 125 scholarly articles and quantitative supporting analysis. We found that land subsidence is overlooked. Although the monitoring measures are progressing towards better technology utilization, it was not properly integrated into mitigation and adaptation measures. Instead of investing more on developing better urban water management, groundwater extraction still became the preferred water source. Thus, there is a major shift needed with regard to urban activities that need to pay more heed to the environment.
\end{abstract}

Keywords: coastal city; land subsidence; Semarang; progress

\section{Introduction}

Dealing with land subsidence is a massive challenge. Land subsidence is irreversible environmental degradation [1-5] that threatens the future of a city [6,7]. Unlike any other disastrous event, this silent disaster happened at an exceedingly slow rate so that the impact may only be assessed years after [8-11]. Land subsidence portrays the complexities on how urban activities are not merely affecting the surface environment, but also the subsurface resources, as it is caused by changes in and movement of underground materials [3,7]; most importantly, the over-exploitation of groundwater due to the need for providing water sources [4,11-15]. In low-lying coastal cities, land subsidence might cause the climaterelated flood-prone areas to broaden [16-18]. Moreover, land subsidence rates are often higher than global ever-rising sea level $[19,20]$. Consequently, land subsidence can be contributing to the future submerging of coastal cities, making them uninhabitable [3]. Cities are even more vulnerable when the local government and the people are lacking awareness about the hazards and impacts of land subsidence [11]. This may lead to mistakes in decision-making, and thus the measures taken become ineffective [10].

Land subsidence had become the international concern in the last four decades. The United Nations Education, Scientific and Cultural Organization (UNESCO) held the first international level knowledge-sharing of land subsidence on 1965. To date, the working group is continuing their work on assisting cities to better deal with the consequences of unsustainable land and water utilization through the Land Subsidence International Initiative. The international support is ranging from providing better monitoring data 
and research on how to include land subsidence in the flooding estimation until how the governance framework that shall be implemented.

To better deal with this hazard, cities need to make significant commitments to taking proactive measures [21]. Innovative and integrative action, as taken by Shanghai, China on integrating groundwater extraction and recharge monitoring and urban development to develop better land use and zoning policy led them to decrease their land subsidence rates by twofold [14]. In Japan, groundwater extraction restrictions had also successfully halted the subsidence rates as their land was stabilized [22]. Unfortunately, not all cities had the capability to do this.

Semarang City, a coastal city in Central Java Province, Indonesia, is one of the national strategic activity centers that connects the eastern and western part of the island. This 373-kilometre square city is home to about 1.8 million people. Well known as "the city where its rivers are flooding", the government had acted with regard to flooding-related issues, as they pioneered participation in the 100 Resilient Cities program [23], joined the Asian Cities Climate Change Resilience Network (ACCRN) in 2009 [24], and took part in the Water As Leverage pilot project [25]. But this city is still under the threat of being sunk $[3,26]$. Water needs that have increased by more than $960 \%$ since 1910 are not fully met by the local water provider [25]. Consequently, the land subsidence rate is still severe, reaching about 24-36 cm/year through 2014-2017 [22]. An estimation by Sarah [27] stated that land subsidence in this city has caused 3.5 trillion rupiah ( \pm 245 billion USD) in economical loss. However, this hazard is not well incorporated into their planning and development policies [28].

Land subsidence in coastal cities is a complex environmental problem. It is related to urban development and land utilization that does not comply with the ecological threshold. Economic activity undertaken by industry is exploiting the groundwater, social justice where the local residents having limited access to water, the building loads that is hard to control so then exceeding its bearing capacity, as well as the geological phenomenon where the subsiding land of this city is actually lying on a young sediments that is still in the process of natural compaction $[5,17,19,28-32]$. To achieve comprehension of the complexities and dynamics of the socio-ecological system and further address the risk of land subsidence, there is a need for an inter-disciplinary approach $[19,33]$ and integrated analysis [3,34-36] and management [28,37-40], in addition to the involvement of multiplestakeholders [39]. However, comprehensive discussions on land subsidence in Semarang city are still limited. Abidin et al. [41] comprehensively assessed the characteristics, impact, and causes of land subsidence in Semarang. Nevertheless, they did not address criticisms of governmental measures or the current adaptive measures undertaken by the community. Another comprehensive study was undertaken by Saputra et al. $[10,26,32]$ who discussed the government's awareness and people's adaptation. Quite similar to this research, Bott et al. [19] also assessed the risk perception and adaptation measures taken by the locals, but they first explored the physical processes. However, those studies only partially discuss the multi-year progress and possible improvements with regard to how this city deals with land subsidence.

This research is aimed to understand the journey of how the Semarang government, people, and researchers explored improvement in taking such an innovative approach in dealing with land subsidence as well as the challenges and limitations in doing so. Specifically, we aim to address the following questions: (1) Is land subsidence monitoring advancing? (2) Are there any similar understandings that land subsidence is a man-made disaster? (3) What is the public's and the government's awareness of land subsidence's enormous impact on coastal ecological and social system?; and (4) How effective are the adaptation and mitigation measures taken by the government and the people? 
The following section contains a detailed description of the research methodology. Then, this article presents the initial insight of the result, including a word cloud analysis. It then takes a deep dive into answering the research question in Sections 3.2-3.4. Some key challenges and problems then discussed in Section 4. Conclusions and some lists of recommendations are then presented in Section 5. Lastly, the references and supporting Appendix A (timeline of land subsidence monitoring studies) and Appendix B (annual subsidence rates monitoring result) can be found at the end of this paper.

\section{Materials and Methods}

A literature review is useful to assess and evaluate prior studies with the aim of finding gaps in knowledge and to better position the need for further research [42]. To do this, we had to dive into numerous resources that fortunately are stored and provided by various databases. In aiming to minimize the bias in choosing the resources, this research used a systematic literature review method [43]. Not merely that, a systematic review also provides the ability to provide answers and understanding that cannot be answered by individual research [44], which is aligned with the aim of this study. One of the most widely accepted guidelines within the scholars for the systematic review is The Preferred Reporting Items for Systematic Reviews, and Meta-Analyses (PRISMA) Guideline [44]. It was used to guide the literature search and iteration process, identify the systemic synthesis path, and generate the initial point of discussion. The guideline consists of a checklist and framework to help systematic reviewers report the analysis by scrapping previous literature in the online academic database. This guideline is used to guide the researcher in providing complete report in systematic review research. Previously, Oliveira et al. [43] used the guideline to explore the role of strategic planning in solving land degradation. Bielecka [45] applied it to understand GIS-Modelling trends in assessing changes in land use.

A literature search executed in July 2021 was done using the Google Scholar (GS), Scopus, and DOAJ databases. The GS databases from Google Corporation was used because it stores a range of scholarly publications such as journal articles, books, opinion letter, etc., from cross-disciplinary fields of study [43]. The data extracted from GS was then combined with the other two databases. The Scopus database from the Elsevier B.V. was added, as it is also contains a large number of peer-reviewed literature [46]. Lastly, the Directory of Open Access Journals or (DOAJ), managed by Lund University is also used, as it is the largest repository that not only provides reputable articles but also allows the public to access them [47]. The words "land" AND "subsidence" AND "monitoring" AND "Semarang" were used as search queries in those three databases. We obtained only three articles from the DOAJ, 11 articles from Scopus, and 1080 articles were initially identified from the GS. However, as the GS has limitations in being too wide and is sorted based on relevance to the keywords, the search threshold was further scaled down to 150-200 of the best compelling articles as recommended by Haddaway et al. [48]. This resulted in a total of 253 articles, which were systematically iterated based on the following criteria: (i) the study location should include the city of Semarang; (ii) the study should be presented as a full report; (iii) the study should substantially discuss land subsidence; and (iv) the literature should not be a duplicate of other resources (Figure 1). Finally, 125 articles were selected from the process to be further reviewed in this paper.

Three main software platforms were employed to analyze the above articles. Microsoft Excel was used to manually iterate the articles and to visualize quantitative data. Atlas.ti 9.1 was used for computer-aided coding analysis, word cloud generation, as well as code and categorical network development. In addition, Mendeley Desktop 1.19.8 was used as a reference manager. Data visualization was done using Origin 9.1., a software that can create multiple $\mathrm{x}$ - and $\mathrm{y}$-graphics. 


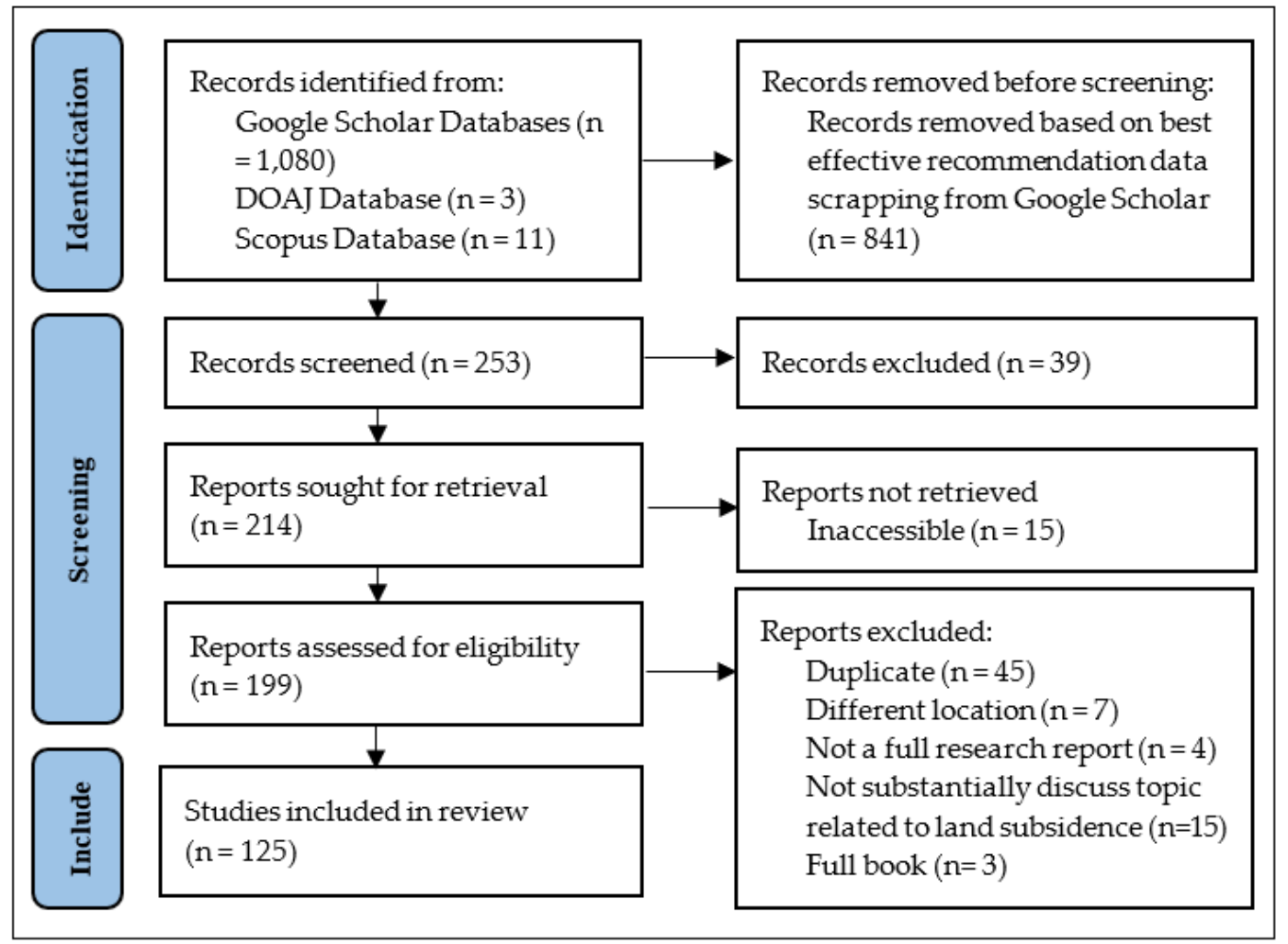

Figure 1. PRISMA systematic review flow diagram showing the process of the literature screening process.

\section{Results}

\subsection{Data Description and Initial Insight}

The three most dominant sources of the reviewed literature were Conference Proceedings (37\%), International Journals (31\%), and National Journals (26\%). We also included other academic sources such as theses, reports, and book chapters. According to the year-based tabulation, as shown in Figure 2, there was an increment in land subsidence research in the last two decades. Although there was a decline from 2019 to 2020, the number of published research followed a linear trendline. Another significant decrease happened between 2020-2021, presumably related to the execution period of this study. Such increment is a positive sign of progress in understanding land subsidence.

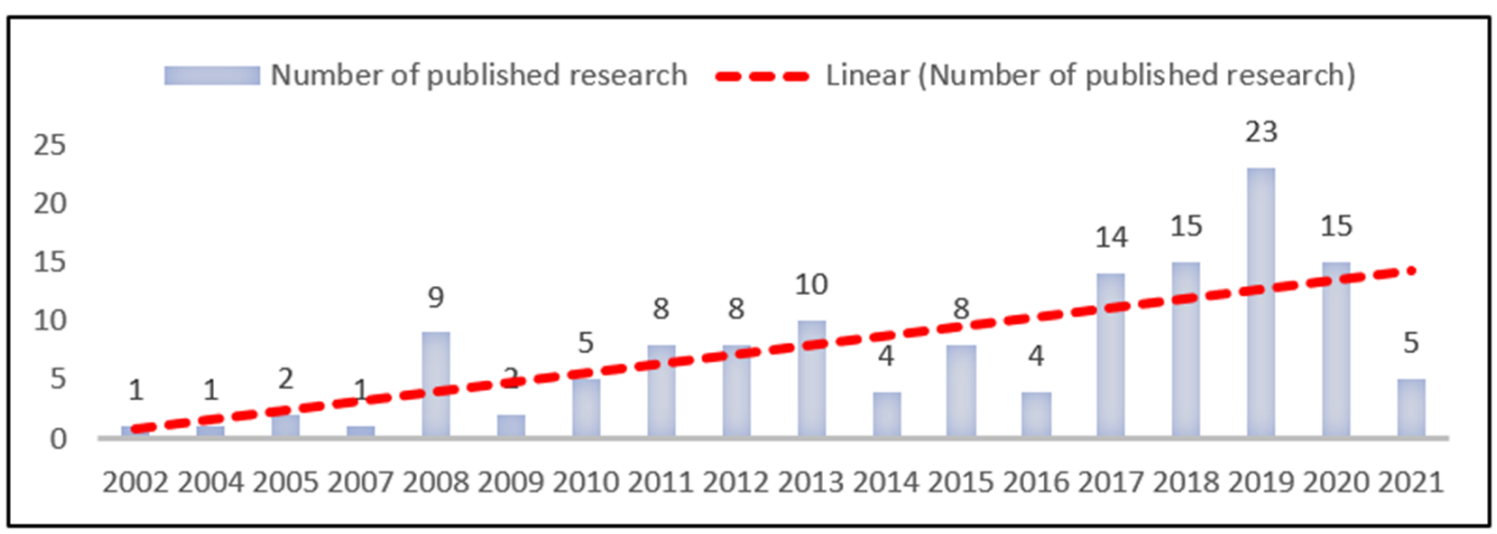

Figure 2. The increasing number of land subsidence research. 
Another initial insight was gained from a word cloud generated using Atlas.ti. As shown in Figure 3 below, "water" and "groundwater" are among the most discussed terminologies in the reviewed papers, as their font size is larger than the other. This shows that the water management perspective is deeply included in land subsidence discussions. The word cloud also provides a preliminary understanding on the broadness of topics reviewed in this paper. Although we used "monitoring" as part of the search query, it does not necessarily mean that the papers generated from the search are limited to monitoring measures. This explains why the font size for the term "monitoring" (Figure 3; lower left) is relatively small and comparable to that for "management" and "adaptation".

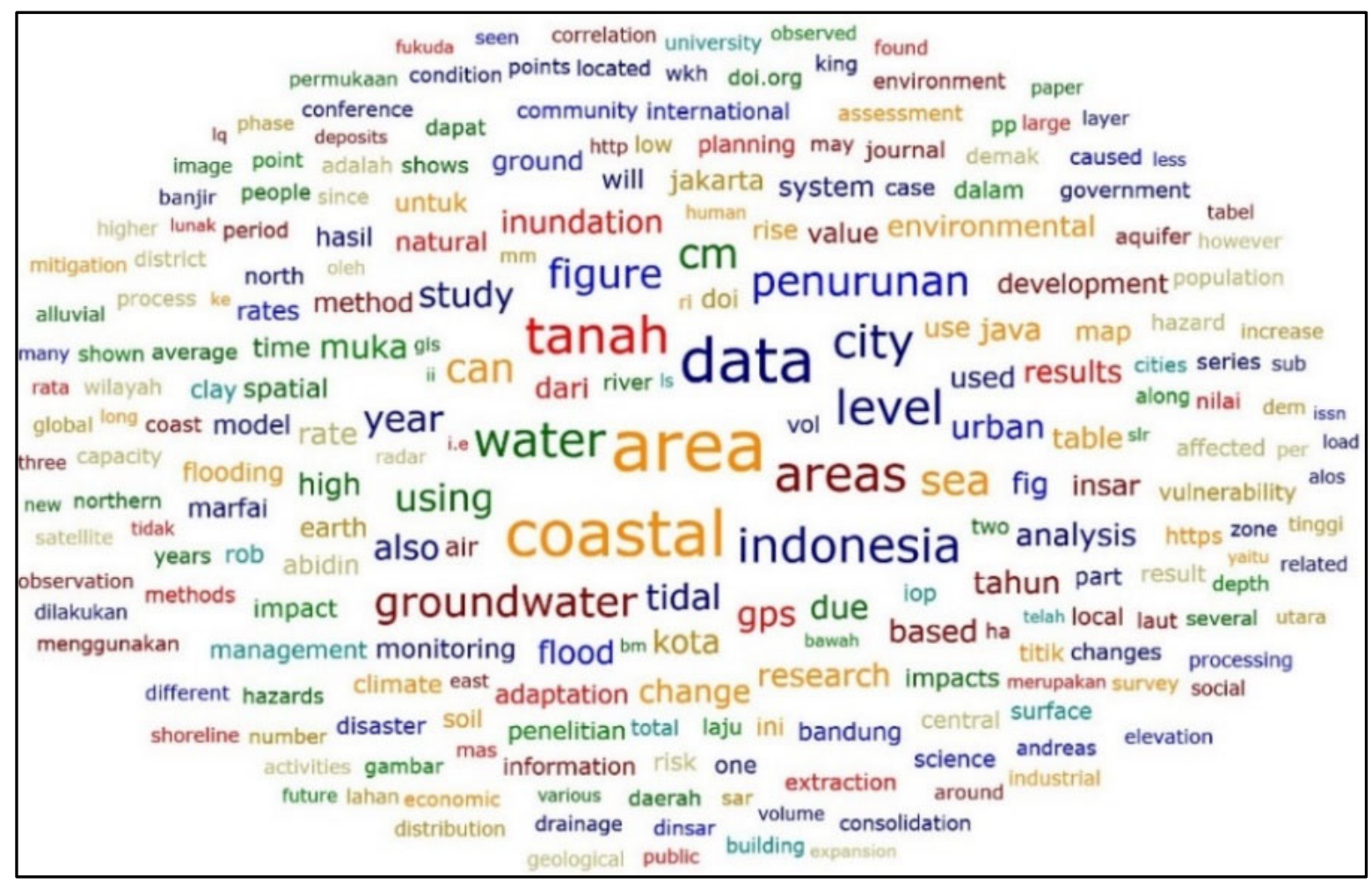

Figure 3. Word cloud generated from literatures reviewed in this paper using Atlas.ti 9.1. Only words with a minimum of 131 mentions were included, while "Semarang" and "Land Subsidence" were excluded from the analysis. Font size indicates frequency of terminology use, in which larger font size shows that the word is mentioned more often in the reviewed papers.

\subsection{Advancement in Land Subsidence Rate Monitoring Measures}

Land subsidence rate monitoring is assessing land elevation differences between a specific time range. This process could be used to provide a comprehensive understanding of the spatial pattern, rates, and displacement of land subsidence $[1,49,50]$ by assessing elevation changes over time [2,22] and to estimate future conditions [3,51]. This is also the initial step in mitigating the risk of land subsidence [1,52-54]. Effective monitoring measures is necessary to help developers or individuals to take the best action in adapting to subsidence [8]. Better management of land utilization and water supply could also be achieved $[2,3,8,53,55,56]$.

The most severe land subsidence rates were reported in the northeastern part of the coastal area in Semarang [35,57-65]. According to the spatial estimation, land subsidence occurs in $32.92 \%$ of the city area, which is about $128.65 \mathrm{~km}^{2}$ [66]. The western part of the city has a relatively lower risk for land subsidence $[35,58,67]$. Land use activities that are related to the highest subsidence rates are: (1) port and sea transportation activities at Tanjung Emas Harbour (Pelabuhan Tanjung Emas) [52,61,68,69]; (2) industrial areas [1,70-72] 
(Genuk District [4,5,70,73], North Semarang District [4,69]); (3) housing areas [52,70,74]; and (4) an old city post-Dutch quarter tourism area [2].

As shown in Appendix A, the maximum annual subsidence rates observed in the coastal area of Semarang are up to 15-19 cm/year. The rates in 2008-2010 were relatively steady, while an increase was observed in 2010 and so forth $[60,63]$. On the other hand, benchmark data assessed by Suprabadevi et al. [65] showed that the highest accumulative subsidence rate was observed at $33.5 \mathrm{~cm}$ in 2008-2011.

As shown in Figure 4, in the 1980s, monitoring was done based on geodetic measurement using the ground-levelling technique by installing grounded concrete piles or conducting a ground survey using Global Positioning System (GPS) tools. However, as this method relies on the subsiding ground, its stability and continuity are questionable. Hence, in the 2000s, satellite imagery that can encompass a wider area and better data availability was used for long-term monitoring. Critical reviews also stated that this method had flaws, such as overestimation and the "no-subsidence" bias caused by low coherence data.

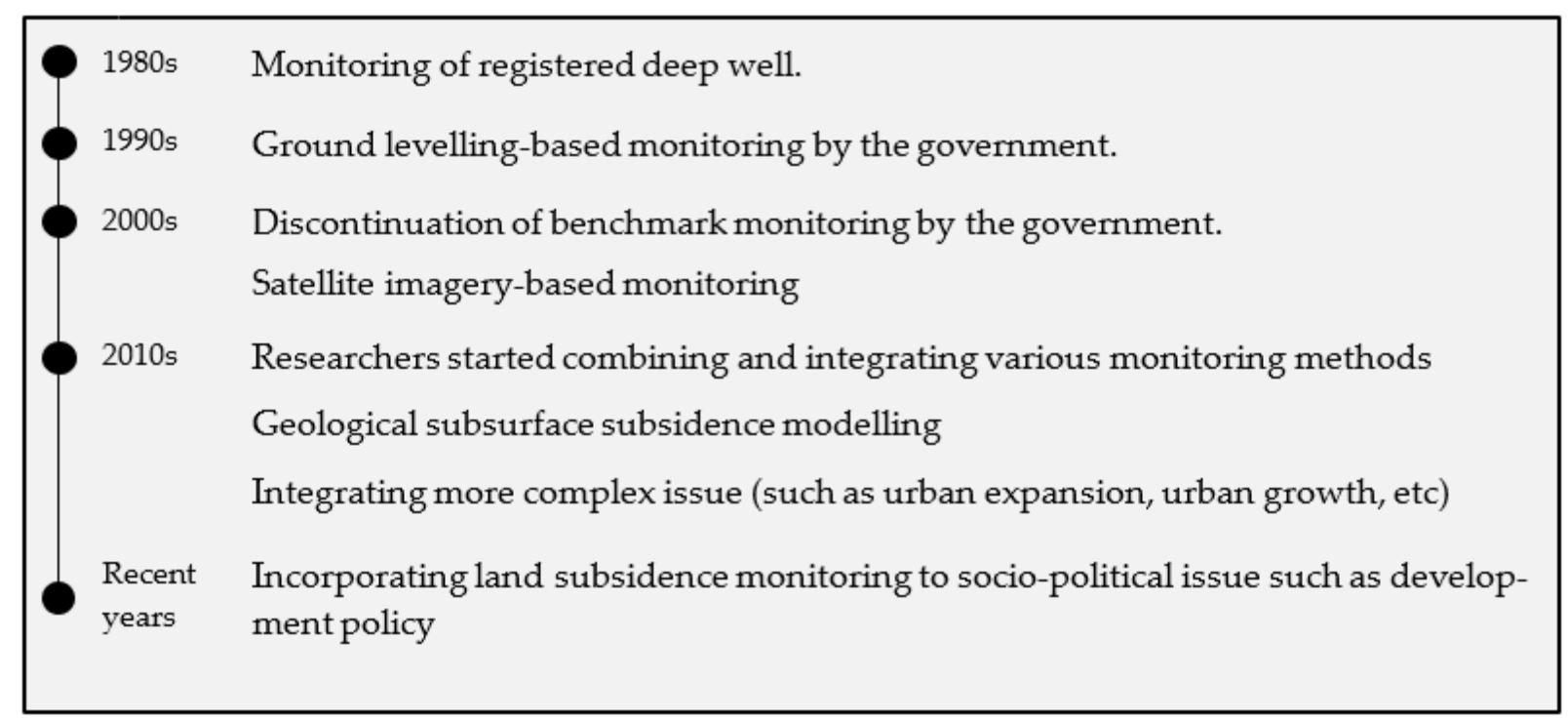

Figure 4. Historical timeline of land subsidence monitoring in Semarang $[3,22,25,28,30,36,51,54,75,76]$.

Monitoring is done in various models that might lead to different results corresponding with different perceived impacts $[61,70]$. This has the potential to mislead the mitigation and adaptation projects [75]. As there is limited research showing accumulative subsidence rates, this may also lead to a bias for the actual subsidence events. The Interferometric Synthetic Aperture Radar (InSAR) is a common method used to analyze the rates of subsidence [63] by comparing digital elevation models between two satellite images [77]. Another method, microgravity, effectively measures subsidence based on geological elevation [78]. The Global Positioning System (GPS) is also a remarkable method [63]. Some researchers argue that InSAR is better than the other because it could monitor surface deformation in a large area without risking any device on the subsiding yet unstable soil [57]. Others prefer to utilize InSAR as a complementary technique to confirm each other's results and to test for data reliability $[22,60,71,76,79]$, to confront [34], or merely to highlight any differences [49]. Effective monitoring measures could then be defined as (i) using a combined method, which primarily relies on satellite data (using InSAR) which then supported by field survey and observation (using GPS) and (ii) the ability to provide information not merely about yearly rates but also about the accumulative subsidence. 
Primarily, monitoring measures is dominated by the backcasting technique. The timeline of land subsidence research as shown in Appendix B are all a backcasting estimation (from the recent years and backwards), except from Marfai [3] that also used the forecasting measurement (from recent years and forward). Monitoring measures also dominated by the assessment of the average annual rates rather than the accumulative rates. As shown in Appendix A, the maximum annual subsidence rates observed in the coastal area of Semarang are up to 15-19 cm/year. The rates in 2008-2010 were relatively steady, while an increase was observed in 2010 and so forth $[60,63]$. On the other hand, benchmark data assessed by Suprabadevi at al. [65] showed that the highest accumulative subsidence rate was observed at $33.5 \mathrm{~cm}$ in 2008-2011. The annual rates were almost consistent in the previous decades; this may cause the misunderstanding that land subsidence is a normal condition in Semarang and the subsidence rates in this city will always remain the same. As there is limited research showing accumulative subsidence rates, this may lead to a bias for the actual subsidence events. In addition, accumulative subsidence rates are essential to indicate the urgency of taking further measures in subsiding areas.

\subsection{Debates on Anthropogenic Subsidence Narratives}

Understanding the cause and impact of subsidence is essential in choosing the best adaptation and mitigation measures. Various perspectives regarding this matter may lead to comprehensive understanding, yet at the same time confuse what the priorities are. Researchers, in general, agree that land subsidence is a type of ground surface deformation [57] caused by the consolidation process that lowered the upper soil layer. However, there are ongoing debates on whether the cause is the natural consolidation of young sediment or anthropogenic stressors.

Geological researchers prefer to consider land subsidence as a natural process. Geomorphological processes, mainly sedimentation, have led to land compaction in the coastal areas of Semarang in recent geological years. The coastal area relies on young alluvium sediments that still undergo the process of natural consolidation [34,41,49,52,64,77,80-82]. Fakhri Islam [79] and Yastika et al. [22] indicated that the land subsidence spatial pattern is similar to the young alluvial soil spatial pattern. Such areas consist of a thick, soft layer of clay, gravel, and silt $[41,52,53]$. Masvika [83] did a borehole analysis and then agreed with this proposition.

There are some theoretical understandings and empirical analyses that suggest that land subsidence in Semarang's urbanized coastal area is anthropogenic. In his book, Pipkin [7] categorized natural subsidence as that with a rate of below $4 \mathrm{~cm} /$ year. Another argument from Kuehn et al. [2] stated that natural subsidence "rarely exceeds $1 \mathrm{~cm} /$ year" $^{\prime}$. Geological research for a land subsidence estimation by Sophian [84] showed that although subsidence does occur in areas where natural consolidation is ongoing, this phenomenon could become more severe due to the increasing construction and infrastructure loads in the future. The author reported that land overburdening contributes to half of the subsidence events. Recently, Sarah et al. [85] addressed the debate through natural compaction analysis. They stated that land compaction in Semarang is mainly caused by groundwater exploitation, which results in an over-pressured soil layer. They found that the rate of natural subsidence is relatively low $(0.3 \mathrm{~cm}$ /year $)$ compared to that of the anthropogenic subsidence (17 cm/year). Therefore, they concluded that natural compaction in the case of Semarang is "hardly present".

Empirical research articles further disclosed that land subsidence in Semarang is mainly caused by the overexploitation of groundwater by the urban activity, industries and domestic users. Hadi [86] found that people in the subsiding areas are consuming water from their neighbour's deep wells. Some researchers believed that subsidence has occurred since the 1980s, when the population started to grow rapidly [22,49], groundwater extraction has increased exponentially since then [87]. Some other researchers argue that land subsidence in Semarang has happened since the early 20th century $[50,53,61,87]$. The 
superimposed analysis, where two or more spatial data are is overlapped and analysed using certain spatial analyst software such as ArcGIS, confirms that land subsidence is limited to areas where the aquifer system is overused [71]. Research dedicated to assessing the correlation between the decrease in groundwater levels and land subsidence has proven that both variables are highly correlated [2,49,56,88-92]. In areas experiencing severe subsidence, such as Kaligawe and Genuksari, they also possess a deficit in groundwater [17]. Groundwater extraction has increased because local piped water provision companies cannot fulfil the entire city's domestic and industrial water demand [6,13,25,28,93-96]. On the other side, young alluvium sediments where those activities occur have high groundwater potential $[29,97]$. Land subsidence also induces seawater intrusion, which leads to hydraulic conductivity increments and subsequently increases the subsidence or consolidation rates [98].

Land subsidence is also correlated with urban growth expansion $[4,30,54,69,99,100]$. Land-use change due to industrial area development has occurred in the coastal areas [86]. For example, a total of 698 ha of land in coastal cities has been shifted from agricultural to built-up areas between 1998 and 2008 [101]. Consequently, this caused water recharge disturbance, an increase in groundwater use, and soil overburdening due to increased building loads [1,3,92]. Urbanization in the form of coastal land reclamation also caused land subsidence [102]. Land reclamation projects led to land progression towards the sea [103]. Marshland in coastal areas was buried in developing housing and infrastructures. Combined spatial and temporal analysis showed that the urban development in Semarang was heading towards the coasts in 1998-2018 [104]. Abidin et al. [41] explained that the sedimentation process in Semarang's shoreline is significantly progressing towards the sea, with an average rate up to $8 \mathrm{~m} /$ year from 1965 to the early 1990s. A long-term shoreline analysis from 1903-2003 by Marfai [105] also demonstrated that the 100-year-old coastal seaward progression was not only a result of natural sedimentation but also infrastructure development. Furthermore, reclamation also has a negative impact, as it may change wave patterns, potentially leading to erosion in surrounding areas [37].

Although agreeing with the views of other researchers, Kasfari [56] believes that urban growth determined by population growth will not affect the severity of land subsidence. They came to this conclusion based on their assessment of population and the rates, and they found that the most populated areas are experiencing the slowest subsidence. At the same time, the most sparsely populated international airport is experiencing the fastest subsidence. The subsidence in the new airport development zone is presumably due to required man-made and technologically induced subsidence to stabilize the land, so there will be no subsidence in the future [106]. Therefore, the prior argument might be less relevant to deny the fact that urban development, the anthropogenic stressors, is causing land subsidence.

Based on these insights, we could preliminary conclude that land subsidence in the case of Semarang is mainly anthropogenically induced. As also shown in the codenetwork in Figure 5, the natural process has limited contribution to land subsidence in Semarang. But to understand the impact of manmade activities to the environment, we shall understand how the natural process is going through. The technical practice of this understanding is well presented by Dong et al. [107], who utilizes the geotechnical approach as a control for land use development. 


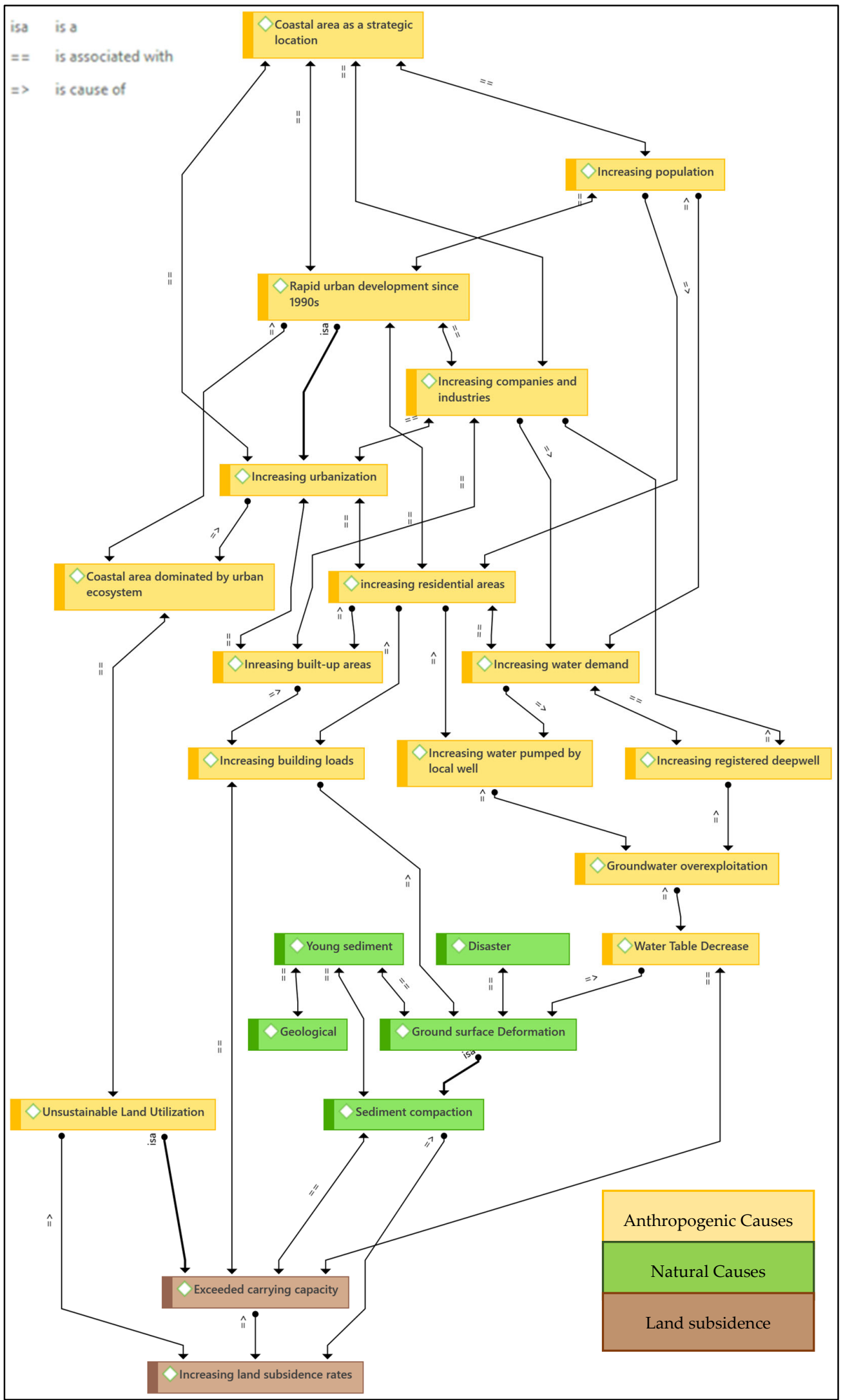

Figure 5. Code-network for the identification of land subsidence causes in Semarang. 


\subsection{People and Public Official Awareness on Land Subsidence Impact and Their Responses}

Land subsidence in low-lying coastal areas created an enormous impact on the city. As discussed in the literature (see Table 1), subsidence has brought the land elevation below sea level. Local land subsidence is the most influential factor that worsens tidal flooding [108]. It also induced erosion, leading to the removal of 1764.5 ha of land in Semarang coastal areas [109]. Suripin and Helmi [109] assessed that the rate of shoreline retreat in 1991-2009 reached $178 \mathrm{~m} /$ year. Andreas et al. [63] used high-resolution satellite imagery analysis to show that the areas surrounding Tanjung Mas and the north-eastern coast of Semarang had been submerged. Marfai [33] predicted that the coastal areas of Semarang city will be submerged further. Land subsidence might cause Semarang to lose its coastal areas in the future $[27,85,109]$.

Table 1. Land subsidence impact.

\begin{tabular}{|c|c|}
\hline Impact & References \\
\hline \multicolumn{2}{|l|}{ Degrading Environmental condition } \\
\hline Worsening tidal flooding exposure & {$[4,8,9,25,29,35,39,41,50,51,63,70,84,108,110-113]$} \\
\hline Submerged/loss of land & {$[4,49,54,63,65,83,109,114]$} \\
\hline Changing shoreline & {$[105,115]$} \\
\hline Seawater intrusion & {$[53,71,101,108,116-118]$} \\
\hline \multicolumn{2}{|l|}{ Physical Infrastructure Destruction } \\
\hline Sinking and abandoned house/building & {$[9,19,76,119]$} \\
\hline Damaging building, road, drainage system & {$[2,8,22,33,76,89,119-121]$} \\
\hline \multicolumn{2}{|l|}{ Economical Loss } \\
\hline \multirow{4}{*}{$\begin{array}{r}\text { Increasing cost of maintenance (household and } \\
\text { government) } \\
\text { Land value decrease } \\
\text { Property value decrease }\end{array}$} & {$[2,8,118]$} \\
\hline & [122] \\
\hline & [114] \\
\hline & {$[62,114]$} \\
\hline \multicolumn{2}{|l|}{ Worsening Social Quality of life } \\
\hline \multirow{4}{*}{$\begin{array}{r}\text { Lowering quality of life } \\
\text { Disrupting local people's day-to-day activity } \\
\text { Increasing coastal vulnerability } \\
\text { Increasing harmful sanitation-related diseases } \\
\text { such as Malaria, Dengue, Labtoferosis, etc. }\end{array}$} & {$[8,19,58,70,72,76,119]$} \\
\hline & {$[26,41,65,114,123,124]$} \\
\hline & {$[2,5]$} \\
\hline & {$[31,52,124,125]$} \\
\hline
\end{tabular}

Towards the city center, it has caused damage to buildings and streets and degraded people's quality of life. The economic loss caused by subsidence in Semarang is estimated at 3.5 trillion Rupiah or 247.9 million USD [27]. A land value assessment by Utami et al. [122] stated that areas impacted by tidal floods and land subsidence suffer from land price stagnation and decrease.

Both the people and the government overlook the matter of land subsidence. As shown in Figure 6, measures taken by both stakeholders are dominated by those that are aimed to tackle coastal flood impact $[28,32,102]$. This contrasts with the fact that the government already knew the importance of tackling land subsidence. They instead took limited measures in dealing with land subsidence. The government initiated subsidence monitoring three decades ago [3] yet discontinued the measure in 2000. In the same year, they also profiled the areas and the people under the risk of land subsidence $[126,127]$. The Semarang Government had also collaborated with GIZ in developing land subsidence monitoring data in 2013. Unfortunately, this project was also discontinued. The government has taken structural (building dykes, pumping stations, flood gates, polder systems, etc.) as well as non-structural measures (seed funding, developing compensation plan, community empowerment, etc.) to mitigate the impact of tidal flooding $[33,124,128]$. They even created specific task forces that focused on every coastal issue and worked on 
monitoring, law enforcement, and infrastructure improvement. Unfortunately, as reported previously [40,126-128], the task force working on land subsidence is focused only on monitoring. The spatial planning document does not incorporate land subsidence either [28]. This might be due to the fact that land subsidence is not considered as a disaster in the national disaster management law. According to Marfai's [33] analysis on the comprehensive flood management system in Semarang, the government of the city did not provide housing or water alternatives. This finding resonates with what was previously reported by Abidin et al. [72].

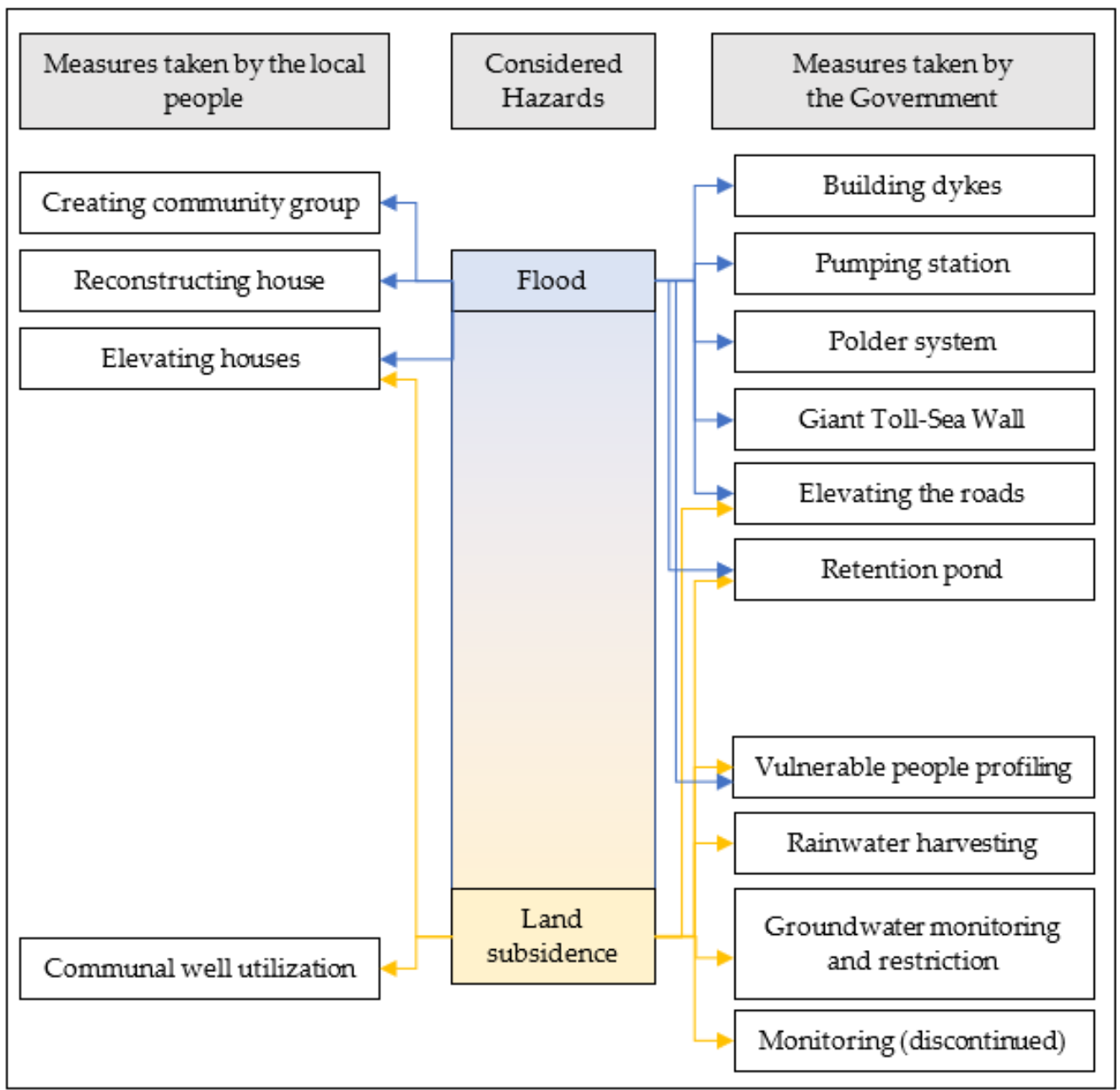

Figure 6. Graphical mapping of measures taken by the government and the people based on considered hazards.

People living in the coastal villages are aware that the tidal flood inundation they suffer from is caused by land subsidence [19,39,127-129]. They know the hazards and risks of such a situation, yet they end up adapting to it rather than moving to a safer location due to several reasons $[128,130,131]$. As mentioned above, affordable housing and water source alternatives are not available. Those who do not have the economic power to obtain housing at a safer location elsewhere have no option but to stay. For some, they refuse to relocate because their livelihood relies on the coastal ecosystem $[123,130,131]$. Even those with higher incomes are reluctant to move because they do not wish to lose their asset ownership in the subsiding areas [131]. 
Various strategies to adapt to tidal floods and land subsidence have been reported. Fauziah [132] found that the social and economic capital highly influence people's adaptability. People in tidal flood-impacted areas established community groups (paguyuban) to strengthen their social capital [124]. Some people use communal wells to fulfill their freshwater needs [130]. They regularly reconstruct their house, such as making overhead furniture to protect their assets during the flood $[123,133,134]$. Their perceived ability to adapt, as a result of the belief that they could improve their environment, also pushes them to elevate the position of their house in respect to surrounding grounds $[19,124,125]$. This has been done at least every five years, as reported by Hadi [124]. People also used trash to build dikes and protect their housing from tidal floods [133].

Critically speaking, these measures are not optimal [135], and may give the false impression of harmony. They could only provide simple, short-term physical solutions that do not necessarily improve the environment [128]. Moreover, measures to elevate the housing grounds create more load to the soil and consequently accelerate the land subsidence rate. This problem is referred to by Saputra [26] as a vicious cycle that the people shall escape. The reason behind it is well-explained by Saharom [136], that people are keen to adapt to the situation, but they are not knowledgeable about ideal housing systems and the use of sustainable and durable materials. The people themselves are aware of such limitations [124].

On the other hand, some people showed a degree of acceptance. They no longer consider tidal floods or land subsidence as a hazard. They believe that tidal flooding is a natural phenomenon that comes from God, and land subsidence is also a natural occurrence that affects everyone in the coastal areas [19].

\section{Discussion}

\subsection{The Unprioritized: Land Subsidence Rate Management}

If land subsidence management is prioritized, the conversation will shift from how much dryland we could save from coastal flooding to how slow the subsidence rates are. In Tokyo and Shanghai, strategies to tackle subsidence are focused on doing whatever it takes to slow down the rates and to stabilize the land [6,22]. According to the local context, Abidin et al. [120] stated that to slow down or to stop land subsidence, the effectiveness of structural measures to protect from coastal flooding should be increased. The land cannot be brought back to its original condition, but its subsidence rate may be slowed down to an acceptable level (below $<1 \mathrm{~cm} /$ year) so that the impact will not be as harsh as it is nowadays. Such priority also brings us to the discussion of the ineffectiveness of dykes or other structural constructs $[120,133]$ and the enhancement of geological measurement in assessing land subsidence management progress. Measures taken shall aim for the improvement of the bearing capacity of the subsiding layer of land [137], the elevation of the decreasing water table [138], and the implementation of integrated water management from watershed to the coasts [33].

As reviewed above, people, government, and researchers tend to discuss flood management more intensively rather than to prioritize land subsidence. Land subsidence itself is considered as one of the predictors in mapping tidal flood exposure in a city [109,111,113,139-142], which is also known as comprehensive flood mapping [141]. As subsidence is a complex process, flood estimation is generally based on the average land subsidence rate [126], despite the fact that the range itself is vast. Therefore, there is more to work on to improve flood mapping efforts [119]. From the technological perspective, the official method for subsidence monitoring is yet well-established [22,63]. Effective monitoring techniques should not only rely on the advancement of technology, data, or software used, but they should also be economically feasible, systematic, continuous, and precise $[8,22,55]$. 
Saputra [32] assessed that the government and people do not channel their awareness about land subsidence towards actions for adaptation and management. Reflecting on the local people's perspective, they prioritize flood over land subsidence mitigation because they perceive that the impact of land subsidence is moderate and not immediate and thus they do not feel the need to focus on it today [128]. In contrast, tidal flood impact is easily visible and it affects them severely every year [128]. However, if we focus more on tidal floods, the expected outcome will be directed towards expanding dry areas, which is non-achievable in a land area that continues to subside. Prioritizing land subsidence as the root cause of coastal flooding is therefore critical.

\subsection{The Less-Considered: Urban Water Management}

Prioritizing the slowing down of land subsidence rates will drive our focus towards achieving more sustainable water management. This shift is important in managing land subsidence [22,51]. As previously discussed in Section 3.3, anthropogenic stressors play an influential role in causing land subsidence. Consequently, human activity shall be radically changed in order to fully implement this shift. The anthropogenic activity and unsustainable groundwater use, is the only one we could control among other land subsidence causes if there is no other physical intervention to reduce the geological loads and control deformation [63]. The goal is to optimize surface water supply so that both the industry's actors and households do not need to exploit the groundwater. The city could provide a better piping system, prevent further excessive groundwater extraction, and balance the water recharge to decrease subsidence to an acceptable rate. Such practices have previously been successfully implemented to control the rates of subsidence in Tokyo, Japan [22] and to prevent further destruction. Relating to this goal, the government has developed some water policies such as the creation of a tax for groundwater extraction through City Regulation Number 08/2011 and the delineation of a groundwater restriction and limitation zone through Semarang City Regulation Number 02/2013 [32]. Although these policies were established years ago, recent research has found that groundwater levels are still decreasing [52].

The groundwater in the coastal areas is unsuitable for consumption. Based on an assessment by Putranto [143], such groundwater is categorized as critically-damaged and not consumable due to its high salinity and heavy metal contamination. This corresponds with Rahmawati and Marfai [101], showing that coastal groundwater consists of mostly saline water. Due to seawater intrusion exaggerated by land subsidence and groundwater extraction, groundwater salinity had increased by a hundredfold throughout 1998-2005, and by 2050, more than half of Semarang's groundwater is projected to become saline and unsuitable for consumption [101]. Buchori et al. [144] predicted that the seawater intrusion might spread to the city centre. Land subsidence may also cause seawater contamination in surface water, leading to an increase in salinity [101]. Therefore, even though relying on surface water might seem to be the most feasible way to deal with groundwater conservation, the water has to be treated before use [25].

Unlike the industrial sector, domestic users do not require a permit for groundwater use. As shown in Figure 7, the number of consumers of the local freshwater provider company was increased in 2004-2014. This was followed by a stagnancy in 2014 to 2017, after which the number continued to increase. It is a good sign that people are more likely to meet their water needs from sustainable piped water. However, these data do not cover any household or consumer that uses a combination of piped and deep-well water as freshwater sources. 


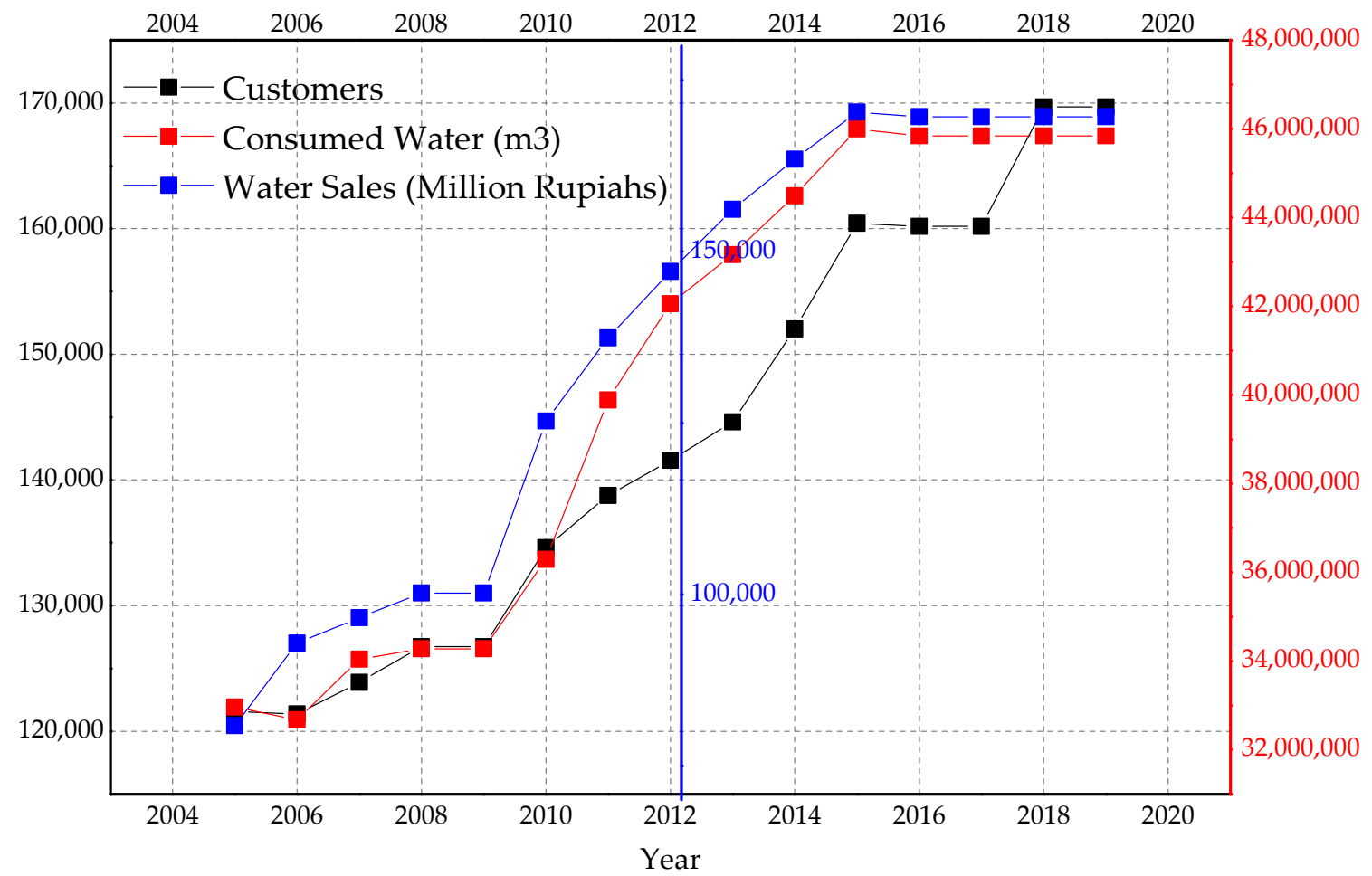

Figure 7. Multi-year trends of water consumption. Source: Bureau of Statistics, Semarang City.

As existing water supply cannot meet water demand $[25,145,146]$, a need to develop a plan for water alternatives is crucial [126]. Unfortunately, this is not an issue that is generally discussed in the literature. Among the reviewed articles, Beek et al. [25] and Hadi et al. [38] were the only ones who discussed alternate solutions to fulfil water demand aside from groundwater extraction. The first article proposed two ideas for water alternatives. The first is the reuse of industrial wastewater for short-term water alternative measures. The second is to develop better water infrastructure to ensure water hygiene. Hadi et al. [38] assessed the use of water retention ponds as fresh water sources integrated with the Giant Sea Wall plan, as well as the measures in reusing surface water through wastewater management, and water source alternative development to cease groundwater extraction. Related to this, the ongoing rainwater harvesting project is had not achieve its maximum potential [97] and its contribution towards reducing land subsidence rates is unclear [32].

On the contrary, the Semarang City Government is still constructing deep wells aiming to provide water for urban residents that is still unreachable by the local water company. As seen in Figure 8, they spent more than two billion rupiah per year (around $\$ 140,000)$ to create what they called an artificial water spring which is actually a deep well. In the 2013-2014 report, they had mentioned that they are aware that this project might actually give more stress to the land and could possibly worsen the occurrence of land subsidence. They also stated that these wells are not in the restriction zone of groundwater extraction.

Earlier in 2020, PT Witteveen Bos Indonesia released a report about land subsidence assessment under the Netherlands-Indonesia cooperation of water management. This is one of the multiple stakeholder initiative practices in Semarang, as this report is developed by a consortium that comprises Witteveen + Bos, Royal HaskoningDHV, Diponegoro University, TwynstraGudde, and Ellipsis Earth Intelligence. As Semarang is one of their focal study cases, it might be a good sign for the better water management in Semarang as long as the government is willing to fully support this initiative and be ready for a major change in Semarang's water provision and management. 


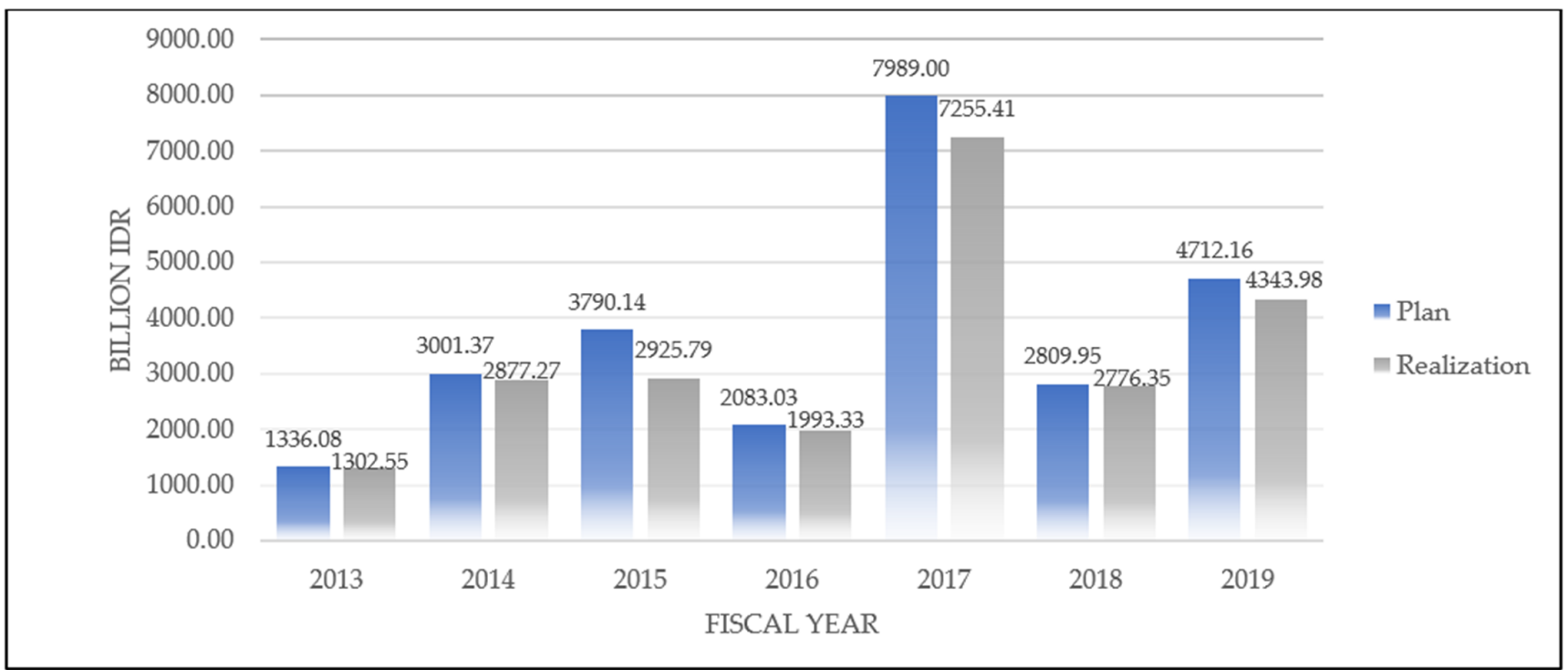

Figure 8. Government yearly spending for deep well construction. (Data taken from Semarang City Mayor's Accountability report from semarangkota.go.id, accessed on 16 November 2021).

\subsection{Problems in Spatial Planning}

Spatial planning played an influential role in dealing with land subsidence. In Shanghai, China, measures to control the land subsidence rates included the increment of land use allocation for green belt and green spaces as well as decreasing the amount of the building plot ratio which was mentioned in their urban plan in 2003 [6]. One of the most successful parts of Shanghai's spatial planning policy that is able to slow the subsidence rates from $12 \mathrm{~mm} /$ year to $6 \mathrm{~mm}$ /year is the land subsidence zoning policy $[6,10]$. The success here is proven by a strong combined monitoring assessment between groundwater withdrawal, groundwater recharge, and subsidence rates monitoring. In contrast, Semarang City still had a long way to go to follow this best practice.

Shanghai and Semarang had some relatively similar potential measures to be taken through spatial planning, such as the stipulation of a green zone, the development of stricter and better building regulations, the mandate to integrate strategic environmental assessments in the spatial planning policy, as well as the stipulation of land subsidence zones. In the Semarang City case, there was only the stipulation of a groundwater extraction restriction zone where we found it contrary with our finding mentioned in Section 4.2 where the government is still preferring to extract groundwater to provide water. In the context of a land use zone, there is another dilemma. Coastal areas are considered protection zones, yet at the same time, they are being allocated as reclamation areas [32]. Furthermore, it is of the highest concern that land subsidence is not a priority and not fully accommodated in spatial planning policies [32]. The monitoring results alone are not yet accommodated into environmental impact assessments as an accompanying document for every planning policy. Content analysis by Hamdani et al. [28] showed that land subsidence rates are incorporated well enough in the environmental assessment document. The problem is how these data are articulated in the policies. There are no specific measures in tackling land subsidence. This type of disaster is not yet considered as a disaster, as reported by the expert team on Land Subsidence for the Coordinating Ministry of Maritime and Investment Affairs in the Republic of Indonesia. Consequently, it is no surprise that the policy does not accommodate the land subsidence and any other potentially derived hydro-meteorological hazards [144]. 
Monitoring measures shall be integrated into decision-making to tackle uncertainties and rapid changes in this era. Researchers still dominate the monitoring process at the moment. Our review showed that there is an abundance of researchers voluntarily dedicating their time to assess the current, past, and future subsidence rates in Semarang. On the other side, the government had taken a path in defining land subsidence in Semarang. Instead of making it public as any other monitoring measure, the result of continuous monitoring had not been published from the 1980s to date [22], and no data is available publicly for research purposes [144].

\section{Conclusions and Recommendations}

Dealing with land subsidence is not easy work. As it is a slow onset disaster, realizing its occurrence is already a huge task to undertake. Monitoring measures dominated by researchers are actually progressing towards technology advancement. In addition, there were also enough intensive empirical evidence-based discussions to conclude that the land subsidence happens in Semarang is human-induced. Unfortunately, those facts are overlooked. The monitoring result is not being incorporated into related policies or programs. Contradictory actions are still found in tackling land subsidence rates, such as restricting groundwater extraction but still using it as the source for water provision, as well as still stipulating that the subsided area is not welcome for new development. Adjusting urban activities and land utilization, which are most important in tackling this anthropogenic subsidence, are still progressing nowhere. On the other hand, although the people had such a great social capital potential, but it is not followed by proper support financially and politically. Thus, false harmony is bringing them progressing backwards by unknowingly bringing their area more vulnerable to future subsidence.

Dealing with land subsidence understood as the implication of unsustainable development then needed a paradigm and a practical shift. In the policy area alone, Indonesian regulations, where the study case policy is referred to, need to shift in regard to define what is considered as a disaster. Future planning and development of coastal cities shall respect the dynamics of submerged land induced by land subsidence. We have listed some room for improvements in planning in Table 2. In the context of monitoring, city officials and researchers could start to find out the accumulative subsidence. The decision-making process shall accommodate land subsidence data in an exemplary manner and shift political interests towards a belief in sustainable development. Future work is needed to understand reliable pathways for creating better water management and land use policies that correspond with current challenges relevant to land subsidence. There is a need for further research that is focused on primary data, such as by interviewing stakeholders and understanding current discussions on the incorporation of land subsidence into spatial planning policies.

Table 2. Room for improvements in spatial planning.

\begin{tabular}{ccc}
\hline Potential & Current Problems/Issues/Challenges & Room for Improvements \\
\hline \multirow{2}{*}{$\begin{array}{c}\text { Progress in developing } \\
\text { comprehensive coastal spatial } \\
\text { planning [33] }\end{array}$} & $\begin{array}{c}\text { Land subsidence (and any other coastal } \\
\text { hazards) is rarely incorporated in spatial } \\
\text { planning [19,28,32] }\end{array}$ & $\begin{array}{c}\text { Designating land subsidence prone areas in } \\
\text { the spatial planning policy [69] }\end{array}$ \\
\cline { 2 - 3 } & $\begin{array}{c}\text { Some vulnerable areas are dedicated as land } \\
\text { reclamation development areas [32,37] }\end{array}$ & $\begin{array}{c}\text { Stipulating no-development zones/limiting } \\
\text { the development or regarding the } \\
\text { deteriorating coastal areas as conservation } \\
\text { zones [19,69] }\end{array}$ \\
\cline { 2 - 3 } & Lack of access to land subsidence data [2] & $\begin{array}{c}\text { Developing interactive and transparent } \\
\text { platform for land use planning [32] }\end{array}$ \\
\hline
\end{tabular}


Table 2. Cont.

\begin{tabular}{|c|c|c|}
\hline Potential & Current Problems/Issues/Challenges & Room for Improvements \\
\hline & $\begin{array}{l}\text { Land use mapping has not been successfully } \\
\text { used to control activities in subsiding areas } \\
\text { [126] }\end{array}$ & Strengthening law enforcement [40] \\
\hline & $\begin{array}{l}\text { Land loss due to permanent flood or coastal } \\
\text { erosion }[2,3,54,63,83,102,108,127]\end{array}$ & $\begin{array}{l}\text { Developing fair land compensation } \\
\text { mechanism }\end{array}$ \\
\hline \multirow{4}{*}{$\begin{array}{l}\text { Increasing urbanization } \\
\text { (population, housing, and } \\
\text { industries) }\end{array}$} & $\begin{array}{l}\text { The housing boom that relies on groundwater } \\
\qquad[1,54,70,103]\end{array}$ & $\begin{array}{l}\text { Controlling housing/real estate } \\
\text { development [82] }\end{array}$ \\
\hline & Groundwater crisis [73] & \multirow{7}{*}{$\begin{array}{l}\text { Regular monitoring and reporting on } \\
\text { land-use change impact to the environment } \\
\text { [40] by optimizing the use of geospatial data } \\
\text { [9] Shift to proactive planning [69] }\end{array}$} \\
\hline & High urban surface loads $[9,19,92]$ & \\
\hline & $\begin{array}{l}\text { Unsustainable land use change } \\
\qquad[30,54,60,69,101,103]\end{array}$ & \\
\hline \multirow{4}{*}{$\begin{array}{l}\text { High participation in relevant } \\
\text { initiatives }[33,39]\end{array}$} & $\begin{array}{l}\text { Toll-road development that will potentially } \\
\text { increase future urban development [147] }\end{array}$ & \\
\hline & Temporary adaptation $[40,72,133]$ & \\
\hline & $\begin{array}{c}\text { Unintegrated embankment development that } \\
\text { worsens flooding [108] }\end{array}$ & \\
\hline & Ineffective mitigation $[72,102]$ & \\
\hline
\end{tabular}

Author Contributions: Conceptualization, R.S.H., S.P.H. and I.R.; methodology, R.S.H., S.P.H. and I.R.; software, R.S.H.; validation, R.S.H., S.P.H. and I.R.; formal analysis, R.S.H.; manuscript preparation, R.S.H., S.P.H. and I.R.; visualization, R.S.H.; supervision, S.P.H. and I.R. All authors have read and agreed to the published version of the manuscript.

Funding: This research received funding from the Directorate of Research and Community Service of the Ministry of Research and Technology/National Research and Innovation Agency of the Republic of Indonesia that has fund this research (Contract Number: 206/SP2H/PMDSU/DRPM/2020).

Institutional Review Board Statement: Not applicable.

Informed Consent Statement: Not applicable.

Data Availability Statement: The data presented in this study are available in Appendices A and B.

Acknowledgments: We are sending our appreciation to the anonymous reviewers and proofreaders that has given substantial influence on the improvement of this manuscript.

Conflicts of Interest: The authors declare that they have no known competing financial interests or personal relationships that could have influenced the work reported in this paper.

\section{Appendix A}

Recapitulation of yearly subsidence rates monitored by various methods and studies. At early stage, technical methods such as using Benchmark (a pipe-sized concrete) is used to monitor the rates. As technology development were arising, researchers started utilizing satellite imagery. Despite that high-tech method are more promising, researchers continue to use conventional ways, such as GNSS, to compare and prove the reliability of their data. 
Table A1. Recap of 30 years of Land subsidence rates observation.

\begin{tabular}{|c|c|c|c|c|c|}
\hline \multicolumn{2}{|c|}{ Monitoring Period } & \multicolumn{2}{|c|}{ Observed Rates (cm/year) } & \multirow{2}{*}{ Method } & \multirow{2}{*}{ Ref } \\
\hline Start & End & Min. & Max. & & \\
\hline & 1984 & 8.1 & $\mathrm{n} / \mathrm{a}$ & Benchmark data & [3] \\
\hline & 1991 & 2.4 & 0.7 & Benchmark data & [3] \\
\hline & 1993 & 5.9 & 2.4 & Benchmark data & [3] \\
\hline 1996 & 1997 & 16.5 & 0.7 & Benchmark data & [3] \\
\hline 2005 & 2006 & 11.33 & 0.267 & $\begin{array}{l}\text { Benchmark data using Geodetic point } \\
\text { (TTG) }\end{array}$ & [61] \\
\hline 2002 & 2006 & $>15$ & $<1$ & $\begin{array}{l}\text { Stable points network (SPN) } \\
\text { technique Friedrich using Synthetic } \\
\text { Aperture Radar satellite images }\end{array}$ & [2] \\
\hline 2003 & 2007 & & & DInSAR & {$[22]$} \\
\hline 2007 & 2008 & 15 & $\mathrm{n} / \mathrm{a}$ & InSAR & {$[50]$} \\
\hline 2007 & 2008 & 11 & 3 & DInSAR & {$[77]^{*}$} \\
\hline 2007 & 2009 & 15 & $\mathrm{n} / \mathrm{a}$ & $\begin{array}{c}\text { Benchmark data; Static survey using } \\
\text { DGPS trimble SR } 20\end{array}$ & [70] \\
\hline 2008 & 2009 & 0.8 & 13.5 & GPS surveys & [50] \\
\hline 2007 & 2009 & 8 & 0 & InSAR & [1] \\
\hline 2002 & 2009 & 15 & 1 & Numerical method (Terzaghi) & [53] \\
\hline 2008 & 2009 & 12.4 & 1 & GPS & [65] \\
\hline 2008 & 2009 & 8.1 & $\mathrm{n} / \mathrm{a}$ & DInSAR & [60] \\
\hline \multirow[t]{3}{*}{2007} & 2009 & 14.13 & 0.78 & DInSAR & [81] \\
\hline & 2009 & 107 & 8.4 & 1D Terzaghi & [82] \\
\hline & 2009 & 103.7 & 17 & PLAXIS & {$[82]$} \\
\hline 2008 & 2009 & 13.5 & $\mathrm{n} / \mathrm{a}$ & GPS & [41] \\
\hline 2007 & 2010 & 8 & $\mathrm{n} / \mathrm{a}$ & DInSAR & [59] \\
\hline 2009 & 2010 & 20.4 & 0 & GPS & [65] \\
\hline 2009 & 2010 & 9.9 & $\mathrm{n} / \mathrm{a}$ & DInSAR & [60] \\
\hline 2009 & 2010 & 18.7 & $\mathrm{n} / \mathrm{a}$ & GPS & [41] \\
\hline 2007 & 2011 & 32 & 0.5 & DInSAR & [57] \\
\hline 2007 & 2011 & & & DInSAR & [22] \\
\hline 2010 & 2011 & 10.5 & 0 & GPS & {$[65]$} \\
\hline 2008 & 2011 & 33.5 & 1.6 & Benchmark data & [65] \\
\hline 2008 & 2011 & 11.2 & 0.53 & Benchmark data & {$[65]$} \\
\hline 2010 & 2011 & 10.7 & $\mathrm{n} / \mathrm{a}$ & GPS & [41] \\
\hline 2013 & 2015 & 13.935 & 0.835 & GPS Analysis of MIT & {$[64]$} \\
\hline 2010 & 2015 & 3.4 & 0.4 & Benchmark data & [58] \\
\hline 2011 & 2015 & 15.4 & 0.2 & GPS & [58] \\
\hline 2008 & 2016 & & & GPS & {$[63]$} \\
\hline 2015 & 2016 & 20.91 & 0.77 & DInSAR & [79] \\
\hline 2015 & 2016 & 13.7 & 3.4 & GPS & [49] \\
\hline 2014 & 2017 & 4.5 & 0 & PS-InSAR & [88] \\
\hline 2014 & 2017 & 4.5 & 0 & PS-InSAR & {$[34]$} \\
\hline 2015 & 2017 & & & DInSAR & {$[22]$} \\
\hline 2016 & 2017 & 18.3 & 0.3 & GPS & [49] \\
\hline \multirow[t]{2}{*}{2016} & 2017 & 10.239 & 0.422 & $\begin{array}{l}\text { PS-InSAR -Standford Method of } \\
\text { Persistent Scatterers (StaMPS) }\end{array}$ & [80] \\
\hline & 2017 & 0.3 & 0.03 & Microgravity & [148] \\
\hline 2017 & 2018 & 19.1 & 0.1 & GPS & [49] \\
\hline 2015 & 2018 & 15.8 & 0.1 & Small Baseline Area Subset (SBAS) & {$[66]$} \\
\hline 2015 & 2018 & 6.753 & 0 & PS-InSAR & [62] \\
\hline 2018 & 2019 & 7.796 & 1.795 & GNSS & [68] \\
\hline 2017 & 2019 & 12.1 & $\mathrm{n} / \mathrm{a}$ & DInSAR & [35] \\
\hline 2017 & 2019 & 12.7 & 0 & DInSAR & [52] \\
\hline
\end{tabular}




\section{Appendix B}

Timeline of land subsidence monitoring studies analysed in this paper. Only one study used forecasting approach Marfai and King [3], whereas majority of land subsidence monitoring research is focused on monitoring and reviewing current or past conditions.

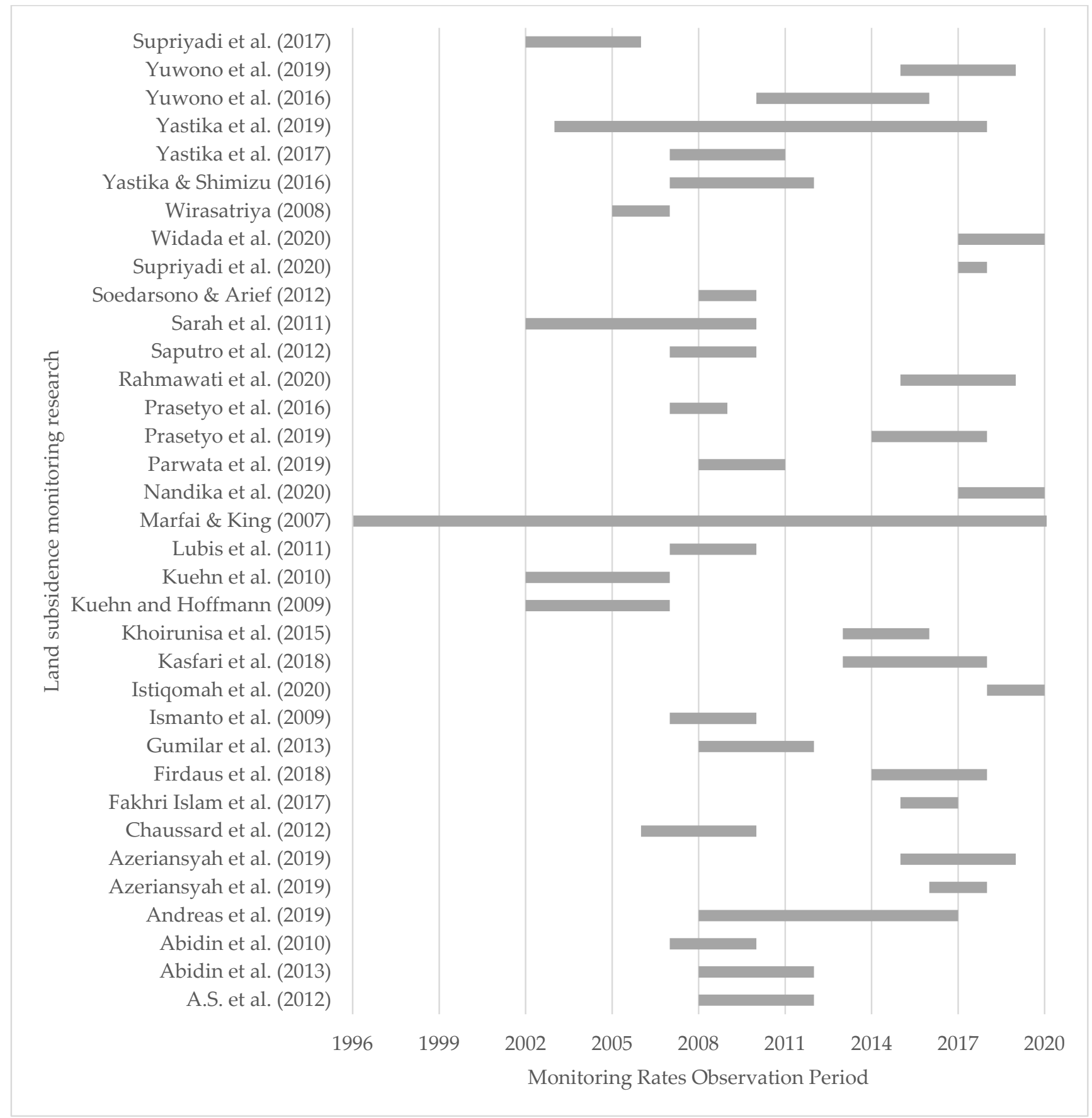

Figure A1. Land subsidence monitoring observation timeline $[1,2,4,22,41,50,52,53,56-59,61-68,70,74,77-82,88,89,148]$.

\section{References}

1. Lubis, A.M.; Sato, T.; Tomiyama, N.; Isezaki, N.; Yamanokuchi, T. Ground subsidence in Semarang-Indonesia investigated by ALOS-PALSAR satellite SAR interferometry. J. Asian Earth Sci. 2011, 40, 1079-1088. [CrossRef]

2. Kuehn, F.; Albiol, D.; Cooksley, G.; Duro, J.; Granda, J.; Haas, S.; Hoffmann-Rothe, A.; Murdohardono, D. Detection of land subsidence in Semarang, Indonesia, using stable points network (SPN) technique. Environ. Earth Sci. 2010, 60, 909-921. [CrossRef] 
3. Marfai, M.A.; King, L. Monitoring land subsidence in Semarang, Indonesia. Environ. Earth Sci. 2007, 53, 651-659. [CrossRef]

4. Chaussard, E.; Amelung, F.; Abidin, H.; Hong, S.-H. Sinking cities in Indonesia: ALOS PALSAR detects rapid subsidence due to groundwater and gas extraction. Remote. Sens. Environ. 2013, 128, 150-161. [CrossRef]

5. Husnayaen; Rimba, A.B.; Osawa, T.; Parwata, I.N.S.; As-Syakur, A.R.; Kasim, F.; Astarini, I.A. Physical assessment of coastal vulnerability under enhanced land subsidence in Semarang, Indonesia, using multi-sensor satellite data. Adv. Space Res. 2018, 61, 2159-2179. [CrossRef]

6. He, X.-C.; Yang, T.-L.; Shen, S.-L.; Xu, Y.-S.; Arulrajah, A. Land Subsidence Control Zone and Policy for the Environmental Protection of Shanghai. Int. J. Environ. Res. Public Health 2019, 16, 2729. [CrossRef] [PubMed]

7. Pipkin, B.; Trent, D.; Hazlett, R.; Bierman, P. Subsidence and Collapse. In Geology and the Environment, 7th ed.; Cengage Learning: Belmont, CA, USA, 2008.

8. Abidin, H.; Andreas, H.; Gumilar, I.; Sidiq, T.P.; Gamal, M. Environmental Impacts of Land Subsidence in Urban Areas of In-donesia. In Proceedings of the FIG Working Week 2015: From the Wisdom of the Ages to the Challenges of the Modern World, Sofia, Bulgaria, 17-21 May 2015.

9. Abidin, H.Z.; Andreas, H.; Gumilar, I.; Sidiq, T.P.; Fukuda, Y. On the Roles of Geospatial Information for Risk Assessment of Land Subsidence in Urban Areas of Indonesia. In Lecture Notes in Geoinformation and Cartography; Zlatanova, S., Peters, R., Dilo, A., Scholten, H., Eds.; Springer: Berlin, Germany, 2012; pp. 277-288.

10. Saputra, E. Land Subsidence as a Sleeping Disaster Case studies from Indonesia. Doctoral Dissertation, Utrecht University, Utrecht, The Netherlands, 2020.

11. Le, T.D.N. Climate change adaptation in coastal cities of developing countries: Characterizing types of vulnerability and adaptation options. Mitig. Adapt. Strat. Glob. Chang. 2020, 25, 739-761. [CrossRef]

12. Basco-Carrera, L.; Van Beek, E.; Jonoski, A.; Benítez-Ávila, C.; Guntoro, F.P.J. Collaborative Modelling for Informed Decision Making and Inclusive Water Development. Water Resour. Manag. 2017, 31, 2611-2625. [CrossRef]

13. Octavianti, T.; Charles, K. De- and Re-politicisation of Water Security as Examined Through the Lens of the Hydrosocial Cycle: The Case of Jakarta's Sea Wall Plan. Water Altern. 2019, 12, 1017-1037.

14. Wu, J.; Shi, X.; Xue, Y.; Zhang, Y.; Wei, Z.; Yu, J. The development and control of the land subsidence in the Yangtze Delta, China. Environ. Geol. 2008, 55, 1725-1735. [CrossRef]

15. Handayani, W.; Chigbu, U.E.; Rudiarto, I.; Putri, I.H.S. Urbanization and Increasing Flood Risk in the Northern Coast of Central Java-Indonesia: An Assessment towards Better Land Use Policy and Flood Management. Land 2020, 9, 343. [CrossRef]

16. IPCC. Summary for Policy Makers. In Climate Change 2014: Impacts, Adaptation, and Vulnerability. Part A: Global and Sectoral Aspects. Contribution of Working Group II to the Fifth Assessment Report of the Intergovernmental Panel on Climate Change; Barros, V.R., Field, C.B., Dokken, D.J., Mastrandrea, M.D., Mach, K.J., Billir, T.E., Kissel, E.S., Chatterjee, M., Levy, A.N., Ebi, K.L., et al., Eds.; Cambridge University Press: Cambridge, UK; New York, NY, USA, 2014.

17. Sarah, D.; Soebowo, E. Land subsidence threats and its management in the North Coast of Java. In Proceedings of the Global Colloquium on GeoSciences and Engineering 2017, Bandung, Indonesia, 18-19 October 2017.

18. Rudiarto, I.; Pamungkas, D. Spatial Exposure and Livelihood Vulnerability to Climate-Related Disasters in The North Coast of Tegal City, Indonesia. Int. Rev. Spat. Plan. Sustain. Dev. 2020, 8, 34-53. [CrossRef]

19. Bott, L.-M.; Schöne, T.; Illigner, J.; Haghighi, M.H.; Gisevius, K.; Braun, B. Land subsidence in Jakarta and Semarang Bay-The relationship between physical processes, risk perception, and household adaptation. Ocean Coast. Manag. 2021, 211 , 105775. [CrossRef]

20. Takagi, H.; Esteban, M.; Mikami, T.; Pratama, M.B.; Valenzuela, V.P.B.; Avelino, J.E. People's perception of land subsidence, floods, and their connection: A note based on recent surveys in a sinking coastal community in Jakarta. Ocean Coast. Manag. 2021, 211, 105753. [CrossRef]

21. Ashley, C.; Alonso, E.E.; Romano, O. Sinking cities: What economic and governance conditions lead to greater resilience? In Proceedings of the Second International Conference on Water, Megacities and Global Change, Paris, France, 7-11 December 2020.

22. Yastika, P.E.; Shimizu, N.; Abidin, H. Monitoring of long-term land subsidence from 2003 to 2017 in coastal area of Semarang, Indonesia by SBAS DInSAR analyses using Envisat-ASAR, ALOS-PALSAR, and Sentinel-1A SAR data. Adv. Space Res. 2019, 63, 1719-1736. [CrossRef]

23. Ekopriyono, A. Semarang City's Resilient Strategy Facing Covid-19. J. Sos. Hum. 2021, 25-34. [CrossRef]

24. Jarvie, J.; Sutarto, R.; Syam, D.; Jeffery, P. Lessons for Africa from urban climate change resilience building in Indonesia. Curr. Opin. Environ. Sustain. 2015, 13, 19-24. [CrossRef]

25. Beek, W.; Letitre, B.; Hadiyanto, H.; Sudarno, S. Alternatives to groundwater abstraction as a measure to stop land subsidence: A case study of Semarang, Indonesia. In E3S Web of Conferences, Proceedings of The 4th International Conference on Energy, Environment, Epidemiology, and Information System (ICENIS 2019), Semarang, Indonesia, 7-8 August 2019; EDP Sciences: Les Ulis, France, 2019; Volume 125, p. 01003.

26. Saputra, E.; Spit, T.; Zoomers, A. Living in a Bottomless Pit: Households' Responses to Land Subsidence, an Example from Indonesia. J. Environ. Prot. 2019, 10, 1-21. [CrossRef] 
27. Sarah, D.; Satriyo, N.A.; Mulyono, A. Kajian awal estimasi kerugian fisik akibat amblesan tanah di Kota Semarang (in Bahasa Indonesia). In Peran Penelitian Geoteknologi untuk Menunjang Pembangunan Berkelanjutan di Indonesia, Proceedings of the Prosiding Pemaparan Hasil Penelitian Pusat Penelitian Geoteknologi LIPI, Bandung, Indonesia, 2 November 2014; Hery, H., Robert, M.D., Edi, P.U., Harjanto, S., Haryadi, P., Herryal, Z.A., Eko, T.S., Eko, S., Heru, S., Eds.; Pusat Penelitian Geoteknologi Lembaga Ilmu Pengetahuan Indonesia (LIPI): Bandung, Indonesia, 2015; pp. 37-45.

28. Hamdani, R.S.; Hadi, S.P.; Rudiarto, I.; Purnaweni, H. Do we care enough? revisiting land subsidence and coastal spatial planning policy in Semarang, Indonesia. In E3S Web of Conferences, Proceedings of The 5th International Conference on Energy, Environmental and Information System (ICENIS 2020), Semarang, Indonesia, 12-13 August 2020; EDP Sciences: Les Ulis, France, 2020; Volume 202, p. 06005.

29. Marfai, M.A.; King, L. Tidal inundation mapping under enhanced land subsidence in Semarang, Central Java Indonesia. Nat. Hazards 2008, 44, 93-109. [CrossRef]

30. Indrawati, L.; Murti, B.S.S.H.; Rachmawati, R.; Aji, D.S. Effect of urban expansion intensity on urban ecological status utilizing remote sensing and GIS: A study of Semarang-Indonesia. IOP Conf. Ser. Earth Environ. Sci. 2020, 451, 012018. [CrossRef]

31. Marfai, M.A. Impact of sea level rise to coastal ecology: A case study on the northern part of Java island, Indonesia. Quaest. Geogr. 2014, 33, 107-114. [CrossRef]

32. Saputra, E.; Hartmann, T.; Zoomers, A.; Spit, T. Fighting the ignorance: Public authorities' and land users' responses to land subsidence in Indonesia. Am. J. Clim. Chang. 2017, 4, 1-21. [CrossRef]

33. Marfai, M.A.; King, L.; Singh, L.P.; Mardiatno, D.; Sartohadi, J.; Hadmoko, D.S.; Dewi, A. Natural hazards in Central Java Province, Indonesia: An overview. Environ. Geol. 2008, 56, 335-351. [CrossRef]

34. Prasetyo, Y.; Firdaus, H.S.; Diyanah. Land subsidence of Semarang City using Permanent Scatterer Interferometric Synthetic Aperture Radar (Ps-Insar) Method in Sentinel 1A Between 2014-2017. In IOP Conference Series: Earth and Environmental Science, Proceedings of the 3rd Geoplanning International Conference on Geomatics and Planning, Semarang, Indonesia, 29-30 August 2018; IOP Publishing: Bristol, UK, 2019; Volume 313, p. 012044.

35. Nandika, M.R.; Susilo, S.B.; Siregar, V. Vertical land motion and inundation processes based on the integration of remotely sensed data and IPCC AR5 scenarios in coastal Semarang, Indonesia. Int. J. Remote Sens. Earth Sci. (IJReSES) 2020, 16, 121-130. [CrossRef]

36. Abidin, H.Z.; Andreas, H.; Gumilar, I.; Yuwono, B.D.; Murdohardono, D.; Supriyadi, S. On Integration of Geodetic Observation Results for Assessment of Land Subsidence Hazard Risk in Urban Areas of Indonesia. In International Association of Geodesy Symposia; Rizos, C., Willis, P., Eds.; Springer: Cham, Germany, 2015; pp. 435-442, ISBN 978-3-319-30895-1. [CrossRef]

37. Dewi, R.S. Monitoring long-term shoreline changes along the coast of Semarang. In IOP Conference Series: Earth and Environmental Science, Proceedings of The 5th International Symposium on LAPAN-IPB Satellite for Food Security and Environmental Monitoring 2018 (LISAT-FSEM 2018), IPB International Convention Center, Bogor, Indonesia, 6-7 November 2018; IOP Publishing: Bristol, UK, 2019; Volume 284, p. 012035. [CrossRef]

38. Hadi, S.P.; Anggoro, S.; Purnaweni, H.; Yuliastuti, N.; Ekopriyono, A.; Hamdani, R.S. Assessing the giant sea wall for sustainable coastal development: Case study of Semarang City, Indonesia. AACL Bioflux. 2020, 13, 3674-3682.

39. Maimunah, S.; Rosli, N.S.; Rafanoharana, S.; Sari, K.R.; Higashi, O. Strengthening Community to Prevent Flood using Participatory Approach: A case of Semarang City, Indonesia. J. Int. Dev. Coop 2011, 18, 19-28. [CrossRef]

40. Wijaya, N. Climate Change Adaptation Measures in the Coastal City of Semarang, Indonesia: Current Practices and Perfor-mance. J. Perenc. Wil. Dan Kota 2015, 26, 28-42. [CrossRef]

41. Abidin, H.; Andreas, H.; Gumilar, I.; Sidiq, T.; Fukuda, Y. Land subsidence in coastal city of Semarang (Indonesia): Characteristics, impacts and causes. Geomatics Nat. Hazards Risk 2013, 4, 226-240. [CrossRef]

42. Charmaz, K. Constructing Grounded Theory: A Practical Guide through Qualitative Analysis; Sage Publications Ltd: London, UK, 2006.

43. Oliveira, E.; Tobias, S.; Hersperger, A.M. Can strategic spatial planning contribute to land degradation reduction in urban regions? State of the art and future research. Sustainability 2018, 10, 949. [CrossRef]

44. Page, M.J.; McKenzie, J.E.; Bossuyt, P.M.; Boutron, I.; Hoffmann, T.C.; Mulrow, C.D.; Shamseer, L.; Tetzlaff, J.M.; Akl, E.A.; Brennan, S.E.; et al. The PRISMA 2020 statement: An updated guideline for reporting systematic reviews. J. Clin. Epidemiol. 2021, 134, 178-189. [CrossRef]

45. Bielecka, E. GIS Spatial Analysis Modeling for Land Use Change. A Bibliometric Analysis of the Intellectual Base and Trends. Geosciences 2020, 10, 421. [CrossRef]

46. Chapman, E.J.; Byron, C.J. The flexible application of carrying capacity in ecology. Glob. Ecol. Conserv. 2018, 13, e00365. [CrossRef]

47. Ennas, G.; Di Guardo, M.C. Features of top-rated gold open access journals: An analysis of the scopus database. J. Inf. 2015, 9, 79-89. [CrossRef]

48. Haddaway, N.R.; Collins, A.; Coughlin, D.; Kirk, S.A. The Role of Google Scholar in Evidence Reviews and Its Applicability to Grey Literature Searching. PLoS ONE 2015, 10, e0138237. [CrossRef]

49. Yuwono, B.D.; Awaluddin, M. Land Subsidence monitoring 2016-2018 analysis using GNSS CORS UDIP and DinSAR in Semarang. In KnE Engineering, Proceedings of the 1st International Conference on Geodesy, Geomatics, and Land Administration, Semarang, Indonesia, 24-25 July 2019; KnE Publishing: Dubai, UAE, 2019; pp. 95-105.

50. Abidin, H.Z.; Andreas, H.; Gumilar, I.; Sidiq, T.P.; Gamal, M.; Murdohardono, D. Studying Land Subsidence in Semarang (In-donesia) using Geodetic Methods. In Proceedings of the FIG Congress, Sydney, Australia, 11-16 April 2010. 
51. Kahar, S.; Purwanto, W.K. Hidajat, Dampak penurunan tanah dan kenaikan muka laut terhadap luasan genangan rob di Semarang. J. Presipitasi 2010, 7, 83-91.

52. Widada, S.; Zainuri, M.; Yulianto, G.; Satriadi, A.; Wijaya, Y.J. Estimation of Land Subsidence Using Sentinel Image Analysis and Its Relation to Subsurface Lithology Based on Resistivity Data in the Coastal Area of Semarang City, Indonesia. J. Ecol. Eng. 2020, 21, 47-56. [CrossRef]

53. Sarah, D.; Syahbana, A.J.; Lubis, R.F.; Mulyono, A. Modelling of Land Subsidence Along Tanah Mas-Pelabuhan Section Semarang City Using Finite Element Method. Ris. Geol. Dan Pertamb. 2011, 21, 105. [CrossRef]

54. Koch, M.; Gaber, A.; Darwish, N.; Bateman, J.; Gopal, S.; Helmi, M. Estimating Land Subsidence in Relation to Urban Expansion in Semarang City, Indonesia, Using InSAR and Optical Change Detection Methods. In Proceedings of the IGARSS $2019-2019$ IEEE International Geoscience and Remote Sensing Symposium, Yokohama, Japan, 28 July-2 August 2019; pp. 9686-9689.

55. Bagheri-Gavkosh, M.; Hosseini, S.M.; Ataie-Ashtiani, B.; Sohani, Y.; Ebrahimian, H.; Morovat, F.; Ashrafi, S. Land subsidence: A global challenge. Sci. Total. Environ. 2021, 778, 146193. [CrossRef]

56. Kasfari, R.; Yuwono, B.D.; Awaluddin, M. Pengamatan Penurunan Muka Tanah Kota Semarang Tahun 2017. J. Geod. Undip. 2018, 7, 120-130.

57. Yastika, P.E.; Shimizu, N. Applications of DInSAR for Ground Surface Deformation Measurements-Case Studies of Subsidence Measurements and Deformation Detections Due to an Earthquake. In Proceedings of the 37th West Japan Symposium on Rock Engineering, Ube City, Japan, 23 September 2016.

58. Yuwono, B.D.; Abidin, H.Z.; Gumilar, I.; Andreas, H.; Awaluddin, M.; Haqqi, K.F.; Khoirunisa, R. Preliminary survey and performance of land subsidence in North Semarang Demak. In AIP Conference Proceedings, Proceedings of the 5th International Symposium on Earthhazard and Disaster Mitigation (ISEDM), Bandung, Indonesia, 19-20 October 2015; AIP Publishing: College Park, MD, USA, 2016; Volume 1730, p. 60004.

59. Yastika, P.E.; Shimizu, N.; Tanaka, T.; Osawa, T. Multi-temporal Analysis for Differential Interferometry Synthetic Aperture Radar (D-InSAR) and Its Application to Monitoring Land Surface Displcements. Int. J. Environ. Geosci. 2017, 1, 1-11. [CrossRef]

60. Parwata, I.N.S.; Ogawara, K.; Tanaka, T. Land Subsidence Monitoring from ALOS/PALSAR Data By Using D-InSAR Tech-nique In Semarang City, Indonesia. Int. J. Environ. Geosci. 2019, 3, 1-9. [CrossRef]

61. Wirasatriya, A. The Study of Land Subsidence Rate at Coastal Area of Semarang City, Indonesia. In Proceedings of the International Conference Conference Geomatics, Fisheries and Marine Science for a Better Future and Prosperity, Semarang, Indonesia, 21-22 October 2008; pp. 330-338.

62. Azeriansyah, R. Integration PS-InSAR and MODIS PWV Data to Monitor Land Subsidence in Semarang City 2015-2018. In KnE Engineering, Proceedings of the 1st International Conference on Geodesy, Geomatics, and Land Administration, Semarang, Indonesia, 25-26 July 2019; Kne Publishing: Dubai, UAE, 2019; pp. 66-76.

63. Andreas, H.; Abidin, H.Z.; Gumilar, I.; Sidiq, T.P.; Sarsito, D.A.; Pradipta, D. On the acceleration of land subsidence rate in Semarang City as detected from GPS surveys. In E3S Web of Conferences, Proceedings of International Symposium on Global Navigation Satellite System 2018 (ISGNSS 2018), Bali, Indonesia, 21-23 November 2018; EDP Sciences: Les Ulis, France, 2019; Volume 94, p. 04002.

64. Khoirunisa, R.; Yuwono, B.D.; Wijaya, A.P. Analisis Penurunan Muka Tanah Kota Semarang Tahun 2015 Menggunakan Perangkat Lunak GAMIT 10.5. J. Geod. Undip. 2015, 4, 341-350.

65. Suprabadevi, A.S.; Osawa, T.; Merit, I.N. Land Subsidence in Semarang. Ecotrophic: Jurn. Ilmu Lingk. 2012, 7, 111-115.

66. Rahmawati, A.N.T.; Prasetyo, Y.; Sasmito, B. Studi Penurunan Muka Tanah Dengan Metode Small Baseline Area Subset (SBAS) Menggunakan Citra Sentinel-1a (Studi Kasus: Kota Semarang). J. Geod. Undip. 2020, 9, $29-37$.

67. Sarah, D.; Soebowo, E.; Mulyono, A. Model Geologi Teknik Daerah Amblesan Tanah Kota Semarang Bagian Barat. In Proceedings of the Prosiding Pemaparan Hasil Penelitian Pusat Penelitian Geoteknologi, Bandung, Indonesia, 3-4 December 2013.

68. Istiqomah, L.N.; Sabri, L.M.; Sudarsono, B. Analisis penurunan muka tanah Kota Semarang metode survei GNSS Tahun 2019. J. Geod. Undip. 2020, 9, 208-216.

69. Gaffara, G.R.; Hisbaron, D.R.; Marfai, M.A. Land use changes analysis for land subsidence in coastal areas (Case study: North Semarang District). Indones. J. Geogr. 2017, 49, 121-134.

70. Ismanto, A.; Wirasatriya, A.; Helmi, M.; Hartoko, A.; Prayogi. Model sebaran penurunan tanah di wilayah pesisir Semarang. Ilmu Kelaut. 2009, 14, 189-196.

71. Arimoto, M.; Fukushima, Y.; Hashimoto, M.; Takada, Y. Land subsidence in Semarang, Indonesia, observed by InSAR Time-Series analysis using ALOS/PALSAR data. J. Geod. Soc. Japan 2013, 59, 45-66.

72. Andreas, H.; Abidin, H.Z.; Gumilar, I.; Sidiq, T.P.; Yuwono, B. Adaptation and mitigation of land subsidence in Semarang. In AIP Conference Proceedings, Proceedings of the International Symposium on Earth Hazard and Disaster Mitigation (ISEDM) 2016: The 6th Annual Symposium on Earthquake and Related Geohazard Research for Disaster Risk Reduction, Bandung, Indonesia, 11-12 October 2016; AIP Publishing: College Park, MD, USA, 2017; Volume 1857, p. 060005.

73. Putranto, T.T.; Widiarso, D.A.; Susanto, N. Assessment of Groundwater Quality to Achieve Sustainable Development in Semarang Coastal Areas. In IOP Conference Sereries: Earth and Environmental Science, Proceedings of the CITIES 2016 International Conference: Coastal Planning for Sustainable Maritime Development, Institut Teknologi Sepuluh November, Indonesia, 18 October 2016; IOP Publishing: Bristol, UK, 2017; Volume 79, p. 012001. 
74. Yuwono, B.D.; Subiyanto, S.; Pratomo, A.S.; Najib. Time Series of Land subsidence rate on Coastal Demak Using GNSS CORS UDIP and DINSAR. In E3S Web of Conferences, Proceedings of the International Symposium on Global Navigation Satellite System 2018 (ISGNSS 2018), Bali, Indonesia, 21-23 November 2018; EDP Science: Les Ulis, France, 2019; Volume 94, p. 04004.

75. Sabri, L.M. Infrastruktur data spasial mitigasi bencana rob di Kota Semarang. In Proceedings of the Seminar Nasional Mitigasi dan Ketahanan Bencana, Semarang, Indonesia, 26 July 2011; Antonius, G.R., Henny, P.A., Abdul, R., Eds.; Universitas Islam Sultan Agung: Semarang, Indonesia, 2011; pp. 81-87.

76. Prasetyo, Y.; Fakhrudin; Warasambi, S.M. Integrated analysis of differential interferometric synthetic aperture radar (DInSAR) and geological data for measuring deformation movement of Kaligarang fault, Semarang-Indonesia. In Proceedings of the 5th International Symposium on Earth Hazard and Disaster Mitigation, Institut Teknologi Bandung, Indonesia, 19-20 October 2015; AIP Conference Proceedings; AIP Publishing: College Park, MD, USA, 2016; Volume 1730, p. 040005.

77. Supriyadi; Khumaedi; Qudus, N.; Wibowo, P.A.; Gunawan, D. Strategy implementation time lapse microgravity method for monitoring subsidence. In AIP Conference Proceedings, Proceedings of Engineering International Conference (EIC) 2016, Semarang, Indonesia, 5-6 October 2016; AIP Publishing: College Park, MD, USA, 2017; Volume 1818, p. 020057.

78. Fakhri Islam, L.J.; Prasetyo, Y.; Sudarsono, B. Analisis Penurunan Muka Tanah (Land Subsidence) Kota Semarang Menggunakan Citra Sentinel-1 Berdasarkan Metode Dinsar Pada Perangkat Lunak Snap. J. Geod. Undip. 2017, 6, $29-36$.

79. Azeriansyah, R.; Prasetyo, Y.; Yuwono, B.D. Land Subsidence Monitoring in Semarang and Demak Coastal Areas 2016-2017 Using Persistent Scatterer Interferometric Synthetic Aperture Radar. In IOP Conference Series: Earth and Environmental Sciences, Proceedings of the 3rd Geoplanning International Conference on Geomatics and Planning, Semarang, Indonesia, 29-30 August 2018; IOP Publishing: Bristol, UK, 2019; Volume 313, p. 012040.

80. Kuehn, F.; Hoffmann-Rothe, A.; Albiol, D.; Cooksley, G.; Duro, J.; Granda, J.; Haas, S.; Murdohardono, D. Detection of land sub-sidence in Semarang/Indonesia using persistent scatterer interferometry. In Proceedings of the 30th Asian Conference on Remote Sensing, Beijing, China, 18-23 October 2009; Asian Association on Remote Sensing: Tokyo, Japan, 2009.

81. Saputro, E.A.; Kahar, S.; Sasmito, B. Deteksi Penurunan Muka Tanah Kota Semarang Dengan Teknik Differential Interferometric Synthetic Aperture Radar (DInsar) Menggunakan Software ROI_PAC Berbasis Open Source. J. Geod. Undip. $2012,1,2231$.

82. Soedarsono; Arief, R.B. Prediksi Amblesan Tanah (Land Subsidence) Pada Dataran Aluvial di Semarang Bagian Bawah. In Proceedings of the Seminar Nasional Kebijakan dan Strategi Pembang; Infrastruktur Pengembangan Wilayah Berbasis Green Technology, Universitas Sultan Agung: Semarang, Indonesia, 2012; pp. 2-9.

83. Masvika, H.; Adi, A.D.; Faris, F. Evaluasi penurunan konsolidasi tanah di Semarang Utara berdasarkan korelasi N-SPT dengan mv. Rekayasa Sipil 2019, 7, 1-12. [CrossRef]

84. Sophian, R.I. Penurunan Muka Tanah di Kota-Kota Besar Pesisir Pantai Utara Jawa (Studi Kasus: Kota Semarang). Bull. Sci. Contrib. 2010, 8, 41-60.

85. Sarah, D.; Hutasoit, L.M.; Delinom, R.M.; Sadisun, I.A. Natural Compaction of Semarang-Demak Alluvial Plain and Its Relationship to the Present Land Subsidence. Indones. J. Geosci. 2020, 7, 273-289. [CrossRef]

86. Hadi, S.P. The Process, the Impact and the Alternatives of Industrial Development in Central Java, Indonesia. Doctoral Dissertation, University of British Columbia, Vancouver, BC, Canada, 1993. (Unpublished)

87. Marfai, M.A. GIS Modelling of River and Tidal Flood Hazards in a Waterfront City Case Study: Semarang City, Central Java, Indonesia. Master's Thesis, International Institute for Geo-Information Science and Earth Observation, Enschede, The Netherlands, 2003.

88. Firdaus, H.S.; Prasetyo, Y.; Diyanah, D. Spatial Correlation Analysis of Land Subsidence and The Water Table Changes in Unconfined Aquifers Using Sentinel 1-SAR Image and Geographic Information Systems (Case Study: Semarang City-Indonesia). In E3S Web of Conferences, Proceedings of The 3rd International Conference on Energy, Environmental and Information System (ICENIS 2018), Semarang, Indonesia, 14-15 August 2018; EDP Sciences: Les Ulis, France, 2018; Volume 73, p. 03022.

89. Gumilar, I.; Abidin, H.Z.; Sidiq, T.P.; Andreas, H.; Maiyudi, R.; Gamal, M. Mapping and Evaluating the Impact of Land Sub-sidence in Semarang (Indonesia). Indones. J. Geospatial. 2013, 2, $26-41$.

90. Prasetyo, Y.; Bashit, N.; Sasmito, B.; Setianingsih, W. Impact of Land Subsidence and Sea Level Rise Influence Shoreline Change in The Coastal Area of Demak. In Proceedings of the 4th International Conference of Indonesian Society for Remote Sensing, Makassar, Indonesia, 30 October 2018.

91. Yuwono, B.D. Korelasi Penurunan Muka Tanah Dengan Penurunan Muka Air Tanah Di Kota Semarang. Teknik 2013, 34, 188-195. [CrossRef]

92. Sarah, D.; Soebowo, E.; Satrio, N.A.; Syahbana, A.J.; Wirabuana, T.; Wahyudin. 1-Dimensional analysis of land subsidence in Semarang city due to anthropogenic forces. In IOP Conference Series: Earth and Environmental Science, Proceeding of the International Conference on the Ocean and Earth Sciences, Jakarta Selatan, Indonesia, 18-20 November 2020; IOP Publishing: Bristol, UK, 2021; Volume 789, p. 012057.

93. Susanto, N. Stakeholder interactions model of groundwater management in Semarang City/Indonesia. Int. J. GEOMATE 2018, 15, 170-177. [CrossRef]

94. Mechlem, K. Groundwater Governance: The Role of Legal Frameworks at the Local and National Level—Established Practice and Emerging Trends. Water 2016, 8, 347. [CrossRef]

95. Calderhead, A.I.; Martel, R.; Garfias, J.; Rivera, A.; Therrien, R. Sustainable Management for Minimizing Land Subsidence of an Over-Pumped Volcanic Aquifer System: Tools for Policy Design. Water Resour. Manag. 2012, 26, 1847-1864. [CrossRef] 
96. Niemczynowicz, J. Urban hydrology and water management-Present and future challenges. Urban Water 1999, 1, 1-14. [CrossRef]

97. Prihanto, Y.; Koestoer, R.H.; Sutjiningsih, D.; Darmajanti, L. Reprofiling landscape of rainwater harvesting in supporting Semarang urban water resilience. In IOP Conference Series: Earth and Environmental Science, Proceedings of the 3rd International Symposium for Sustainable Landscape Development (ISSLD 2017), Bogor, Indonesia, 14-15 November 2017; IOP Publishing: Bristol, UK, 2018; Volume 179 , p. 012043.

98. Sarah, D.; Hutasoit, L.M.; Delinom, R.M.; Sadisun, I.A.; Wirabuana, T. A Physical Study of the Effect of Groundwater Salinity on the Compressibility of the Semarang-DemakAquitard, Java Island. Geosciences 2018, 8, 130. [CrossRef]

99. Huang, Y.; Jin, P. Impact of human interventions on coastal and marine geological hazards: A review. Bull. Int. Assoc. Eng. Geol. 2018, 77, 1081-1090. [CrossRef]

100. Abidin, H.Z.; Andreas, H.; Gumilar, I.; Fukuda, Y.; Pohan, Y.E.; Deguchi, T. Land subsidence of Jakarta (Indonesia) and its relation with urban development. Nat. Hazards 2011, 59, 1753. [CrossRef]

101. Rahmawati, N.; Marfai, M.A. Salinity Pattern in Semarang Coastal City: An Overview. Indones. J. Geosci. 2013, 8, 107-118. [CrossRef]

102. Andreas, H.; Abidin, H.Z.; Gumilar, I.; Sidiq, T.P.; Sarsito, D.A.; Pradipta, D. Insight into the Correlation between Land Subsidence and the Floods in Regions of Indonesia. In Natural Hazards—Risk Assessment; IntechOpen: London, UK, 2018; Available online: https:/ / www.intechopen.com/chapters / 63411 (accessed on 5 November 2021). [CrossRef]

103. Soedarsono, M.A. Marfai, Monitoring the change of land subsidence in the northern of Semarang due to change of land use on alluvial plain. Analele Univ. Din Oradea Ser. Geogr. 2012, 22, 54-65.

104. Sejati, A.W.; Buchori, I.; Rudiarto, I. The spatio-temporal trends of urban growth and surface urban heat islands over two decades in the Semarang Metropolitan Region. Sustain. Cities Soc. 2019, 46, 101432. [CrossRef]

105. Marfai, M.A.; Almohamad, H.; Dey, S.; Susanto, B.; King, L. Coastal dynamic and shoreline mapping: Multi-sources spatial data analysis in Semarang Indonesia. Environ. Monit. Assess. 2007, 142, 297-308. [CrossRef] [PubMed]

106. Hilman, M.Y. Perencanaan Sisi Udara Bandara Internasional Ahmad Yani Semarang. Undergraduate Thesis, Institut Teknologi Sepuluh, Surabaya, Indonesia, 2017.

107. Dong, M.; Hu, H.; Xu, R.; Gong, X. A GIS-based quantitative geo-environmental evaluation for land-use development in an urban area: Shunyi New City, Beijing, China. Bull. Int. Assoc. Eng. Geol. 2017, 77, 1203-1215. [CrossRef]

108. Irawan, A.M.; Marfai, M.A.; Munawar; Nugraheni, I.R.; Gustono, S.T.; Rejeki, H.A.; Widodo, A.; Mahmudiah, R.R.; Faridatunnisa, M. Comparison between averaged and localised subsidence measurements for coastal floods projection in 2050 Semarang, Indonesia. Urban Clim. 2021, 35, 100760. [CrossRef]

109. Suripin, M. Helmi, The lost of Semarang coastal areas due to climate change and land subsidence. In Proceedings of the 2nd International Conference on Coastal and Delta Areas, Universitas Islam Sultan Agung, Semarang, Indonesia, 19 November 2015; pp. 98-108.

110. Karondia, L.A.; Handoko, E.Y.; Hapsari, H. 3D modelling analysis of sea-level rise impact in Semarang, Indonesia. In IOP Conference Series: Earth and Environmental Science, Proceedings of the Geomatics International Conference 2019, Surabaya, Indonesia, 21-22 August 2019; IOP Publishing: Bristol, UK, 2019; Volume 389, p. 012005.

111. Marfai, M. Impact of coastal inundation on ecology and agricultural land use case study in central Java, Indonesia. Quaest. Geogr. 2011, 30, 19-32. [CrossRef]

112. Putranto, T.T.; Rüde, T.R. Groundwater Problems in Semarang Demak Urban Area, Java Indonesia. In Mitteilungen zur Ingenieurgeologie und Hydrogeologie-Festschrift zum 60. Geburtstag von Univ.-Prof. Dr. Dr. h.c. Rafig Azzam; RWTH Aechen University: Aachen, Germany, 2011; Volume 104, pp. 95-106.

113. Sejati, A.W.; Buchori, I. A GIS Model for Predicting Disaster Prone Areas Affected by Global Sea-Level Rise: A Case Study of Semarang City. In Vulnerability, Resilience, and Sustainability, Proceedings of the 1st International Conference on Regional Development, Department or Urban and Regional Planning Diponegoro University, Semarang, Indonesia, 9-10 November 2010; Biro Penerbit Planologi Universitas Diponegoro: Semarang, Indonesia, 2010; pp. 5-12.

114. Marfai, M.A.; King, L. Potential vulnerability implications of coastal inundation due to sea level rise for the coastal zone of Semarang city, Indonesia. Environ. Geol. 2008, 54, 1235-1245. [CrossRef]

115. Sumaryo, H. Sutanta, Diyon, Pembangunan Basis Data Spasial Untuk Pembuatan Model Prediksi Pengaruh Peurunan Tanah dengan Teknologi.pdf. Gama Sains. 2004, 6, 41-51.

116. Supriyadi; Khumaedi; Purnomo, A.S.P. Geophysical and hydrochemical approach for seawater intrusion in North Semarang, Central Java, Indonesia. Int. J. GEOMATE 2017, 12, 134-140. [CrossRef]

117. Supriyadi; Khumaedi; Yusuf, M.; Agung, W. Using a time lapse microgravity model for mapping seawater intrusion around Semarang. In AIP Conference Proceedings, Proceedings of the 4th International Conference on Theoretical and Applied Physics (ICTAP), Denpasar, Indonesia, 16-17 October 2014; AIP Publishing: College Park, MD, USA, 2016; Volume 1719, p. 030041.

118. Hartawan, F.; Wahyudi, S.I. The real operational cost for managing Semarang river polder drainage system. In IOP Conference Series: Materials Science and Engineering, Proceedings of the 4th International Conference on Civil Engineering Research (ICCER 2020), Surabaya, Indonesia, 22-23 July 2020; IOP Publishing: Bristol, UK, 2020; Volume 930, p. 012074.

119. Wahyudi, S.I.; Adi, H.P.; Schultz, B. Revitalizing and Preparing Drainage Operation and Maintenance to Anticipate Climate Change in Semarang Heritage City. J. Environ. Sci. Eng. B 2017, 6, 17-26. [CrossRef] 
120. Andreas, H.; Abidin, H.Z.; Sarsito, D.A.; Pradipta, D. Insight Analysis on Dyke Protection Against Land Subsidence and The Sea Level Rise Around Northern Coast of Java (Pantura) Indonesia. Geoplanning J. Geomatics Plan. 2018, 5, 101-114. [CrossRef]

121. Tazakka, M.S.; Tirta, B.A.; Popang, M.A. Study of negative skin friction on floating piles foundation due to long-term groundwater extraction in Semarang, Indonesia. In IOP Conference Series: Environmental Science, Proceedings of the International Conference on Geological Engineering and Geosciences, Yogyakarta, Indonesia, 16-18 March 2021; IOP Publishing: Bristol, UK, 2021; Volume 851, p. 012025 .

122. Utami, W.; Wibowo, Y.A.; Permadi, F.B. The Impact of Tidal Flooding on Decreasing Land Values in the Areas of Tugu District, Semarang City. J. Ilmu Lingkung. 2021, 19, 10-20. [CrossRef]

123. Amin, C. Staying Decision Making Process in Disaster Prone Area: A Grounded Theory Method Study on Fishermen Community in Semarang Coast, Indonesia. Humanit. Soc. Sci. Rev. 2019, 7, 322-330. [CrossRef]

124. Hadi, S.P. In Search for Sustainable Coastal Management: A Case Study of Semarang, Indonesia. In IOP Conference Series: Earth and Environmental Science, Proceedings of the 2nd International Conference on Tropical and Coastal Region Eco Development, Bali, Indonesia, 25-27 October 2016; IOP Publishing: Bristol, UK, 2017; Volume 55, p. 12054.

125. Miladan, N. Communities' Contributions to Urban Resilience Process: A Case Study of Semarang City (Indonesia) toward Coastal Hydrological Risk. Doctoral Dissertation, Université Paris-Est, Paris, France, 2016.

126. Marfai, M.A.; King, L. Coastal flood management in Semarang, Indonesia. Environ. Geol. 2008, 55, 1507-1518. [CrossRef]

127. Marfai, M.A.; King, L.; Sartohadi, J.; Sudrajat, S.; Budiani, S.R.; Yulianto, F. The impact of tidal flooding on a coastal community in Semarang, Indonesia. Environmentalist 2007, 28, 237-248. [CrossRef]

128. Marfai, M.A.; Hizbaron, D.R. Community's adaptive capacity due to coastal flooding in Semarang coastal city, Indonesia. Analele Univ. Din Oradea Ser. Geogr. 2011, 1, 209-221.

129. Rudiarto, I.; Handayani, W.; Wijaya, H.B.; Insani, T.D. Land resource availability and climate change disasters in the rural coastal of Central Java-Indonesia. In IOP Conference Series: Earth and Environmental Science, Proceedings of the CITIES 2017: Multi Perspectives on Peri-Urban Dynamics Towards Sustainable Development, Surabaya, Indonesia, 18 October 2017; IOP Publishing: Bristol, UK, 2018; Volume 202, p. 012029.

130. Suryanti, E.D.; Marfai, M.A. Adaptasi masyarakat kawasan pesisir Semarang terhadap bahaya banjir pasang air laut. J. Kebencanaan Indones. 2008, 1, 335-346.

131. Khadiyanto, P.; Soetomo, S.; Hadi, S.P. Settlement adaptation on a seawater tide overflow area at the north part of Semarang, Indonesia. J. Flood Risk Manag. 2017, 10, 535-545. [CrossRef]

132. Fauziah, A.N. Kajian Kerentanan Iklim: Sebuah Penilaian Kembali di Wilayah Pesisir Kota Semarang. J. Pembang. Wil. KOTA 2014, 10, 316. [CrossRef]

133. Ameir, M.J.; Ekomadyo, A.S.; Hutomo, C.S. Cultural Capital of a community to adapt in prone areas with floods, land subsidence and its Architectural representation. Case Study in Bandarharjo Semarang. Local Wisdom J. Ilm. Kaji. Kearifan Lokal 2020, 12, 61-70. [CrossRef]

134. Rudiarto, I.; Rengganis, H.; Sarasadi, A.; Caesar, E. The effectiveness of strategy adaptations on tidal flood in the coastal areas of Sayung, Demak, Central Java, Indonesia. In IOP Conference Series: Earth and Environmental Science, Proceedings of the 1st International Conference on Environment, Sustainability Issues and Community Development, Central Java Province, Indonesia, 23-24 October 2019; IOP Publishing: Bristol, UK, 2020; Volume 448, p. 012090.

135. Wiratuningsih, D.; Setyowati, D.L.; Suhandini, P. The Adaptation of The Society in Coping with Tidal Flood in Kemijen Village Semarang City. J. Educ. Soc. Stud. 2018, 7, 146-153.

136. Saharom, N.S.; Diana, S.C.; Kusyala, D. Alternative Housing System \& Materials Criteria for Land Subsidence Area (Case Study: Bandarharjo, Semarang). In IOP Conference Series: Earth and Environmental Science, Proceedings of the International Conference, Bandung, Indonesia, 11 November 2017; IOP Publishing: Bristol, UK, 2018; Volume 152, p. 012015.

137. Widada, S.; Saputra, S.; Hariadi. Determination of Soft Lithology Causes the Land Subsidence in Coastal Semarang City by Resistivity Methods. In IOP Conference Series: Earth and Environmental Science, Proceedings of the 3rd International Conference on Tropical and Coastal Region Eco Development, Yogyakarta, Indonesia, 2-4 October 2017; IOP Publishing: Bristol, UK, 2018; Volume 116, p. 012092.

138. Pryambodo, D.G. Zonasi penurunan muka air tanah di wilayah pesisir berdasarkan teknik geofisika gaya berat mikro $4 \mathrm{D}$ (Studi kasus: Daerah industri Kaligawe-Semarang). J. Kelaut. Nas. 2017, 10, 151-162. [CrossRef]

139. Suhelmi, I.R. Kajian dampak land subsidence terhadap peningkatan luas genangan rob di Kota Semarang: Impact of land sub-sidence on inundated area extensivication at Semarang City. Ilm. Geomatika 2012, 18, 9-16.

140. Nugroho, S.H. Prediksi luas genangan pasang surut (rob) berdasarkan analisis data spasial di Kota Semarang, Indonesia. J. Lingkung. Dan Bencana Geol. 2013, 4, 71-87. [CrossRef]

141. Suripin; Pujiastuti, R.; Widjonarko. The Initial Step for Developing Sustainable Urban Drainage System in Semarang CityIndonesia. In Procedia Engineering, Proceedings of the Sustainable Civil Engineering Structures and Construction Materials (SCESCM 2016), Bali, Indonesia, 5-2 September 2016; Elsevier Ltd: Amsterdam, The Netherlands, 2017; Volume 171, pp. $1486-1494$.

142. Widada, S.; Zainuri, M.; Yulianto, G.; Satriadi, A.; Wijaya, Y.J.; Helmi, M. Mitigation of floodwaters inundation due to land subsidence in the coastal area of Semarang City. In IOP Conference Series: Earth and Environmental Science, Proceeding of the 5th International Conference on Tropical and Coastal Region Eco Development, Semarang, Indonesia, 17-18 September 2019; IOP Publishing: Bristol, UK, 2020; Volume 530, p. 012006. 
143. Putranto, T.T.; Hidajat, W.K.; Susanto, N. Developing groundwater conservation zone of unconfined aquifer in Semarang, Indonesia. In IOP Conference Series: Earth and Environmental Science, Proceedings of the 2nd International Conference on Tropical and Coastal Region Eco Development, Bali, Indonesia, 25-27 October 2016; IOP Publishing: Bristol, UK, 2017; Volume 55, p. 12011.

144. Buchori, I.; Sugiri, A.; Mussadun, M.; Wadley, D.; Liu, Y.; Pramitasari, A.; Pamungkas, I.T. A predictive model to assess spatial planning in addressing hydro-meteorological hazards: A case study of Semarang City, Indonesia. Int. J. Disaster Risk Reduct. 2018, 27, 415-426. [CrossRef]

145. Prasetyo, Y.; Bashit, N.; Simarsoit, Y. Study of Correlation of Residential and Industrial Growth Pattern in Semarang City to the Aquifer Capacity Changes in the Year 2014-2017. In IOP Conference Series: Earth and Environmental Science, Proceedings of the 4th International Conference of Indonesian Society for Remote Sensing, Makassar, Indonesia, 30 October 2018; IOP Publishing: Bristol, UK, 2019; Volume 280, p. 012001.

146. Bakti, H.; Naily, W.; Lubis, R.F.; Delinom, R.M.; Sudaryanto, S. Penjejak keluaran airtanah lepas patai (KALP) di pantai utara Semarang dan sekitarnya dengan 222Radon. Ris. Geol. dan Pertamb. 2014, 24, 43-51. [CrossRef]

147. Andreas, H.; Abidin, H.Z.; Sarsito, D.A.; Meilano, I. Investigating the tectonic subsidence on Java Island using GNSS GPS campaign and continuous. In AIP Conference Proceedings, Proceedings of the 7th International Symposium on Earth Hazard and Disaster Mitigation (ISEDM) 2017, Bandung, Indonesia, 19-21 November 2017; AIP Publishing: College Park, MD, USA, 2018; Volume 1987, p. 020091.

148. Supriyadi; Khumaedi; Sugiyanto; Heparona, J. Microgravity method to monitor subsidence in Kota Lama area Semarang. In Journal of Physics: Conference Series, Proceedings of the 6th International Conference on Mathematics, Science, and Education (ICMSE 2019), Semarang, Indonesia, 9-10 October 2019; IOP Publishing: Bristol, UK, 2020; Volume 1567, p. 032068. 